\title{
Transport of biodeposits and benthic footprint around an oyster farm, Damariscotta Estuary, Maine
}

\author{
Kara Gadeken ${ }^{\text {Corresp. }, 1,2}$, William C Clemo ${ }^{1,2}$, William Ballentine ${ }^{1,2}$, Steven Dykstra ${ }^{1,2}$, Mai Fung ${ }^{1,2}$, Alexis \\ Hagemeyer $^{1,2}$, Kelly M Dorgan ${ }^{1,2}$, Brian Dzwonkowski ${ }^{1,2}$ \\ 1 Dauphin Island Sea Lab, Dauphin Island, Alabama, United States of America \\ 2 Department of Marine Sciences, University of South Alabama, Mobile, Alabama, United States of America \\ Corresponding Author: Kara Gadeken \\ Email address: kgadeken@disl.org
}

The benthic impact of aquaculture waste depends on the area and extent of waste accumulation on the sediment surface below and around the farm. In this study we investigated the effect of flow on biodeposit transport and initial deposition by calculating a rough aquaculture "footprint" around an oyster aquaculture farm in the Damariscotta River, ME. We also compared a site under the farm to a downstream "away" site calculated to be within the footprint of the farm. We found similar sediment biogeochemical fluxes, geochemical properties and macrofaunal communities at the site under the farm and the away site, as well as low organic enrichment at both sites, indicating that biodeposition in this environment likely does not have a major influence on the benthos. To predict accumulation of biodeposits, we measured sediment erodibility under a range of shear stresses and found slightly higher erosion rates at the farm than at the away site. A microalgal mat was observed at the sediment surface in many sediment cores. Partial failure of the microalgal mat was observed at high shear velocity, suggesting that the mat may fail and surface sediment erode at shear velocities comparable to or greater than those calculated from in situ flow measurements. However, this study took place during neap tide, and it is likely that peak bottom velocities during spring tides are high enough to periodically "clear" under-farm sediment of recent deposits. 
1 Transport of biodeposits and benthic footprint around an oyster farm, Damariscotta

2 Estuary, Maine

3

4 Kara Gadeken $^{1,2}$, William C. Clemo ${ }^{1,2}$, William Ballentine ${ }^{1,2}$, Steven Dykstra ${ }^{1,2}$, Mai Fung ${ }^{1,2}$,

5 Alexis Hagemeyer ${ }^{1,2}$, Kelly M. Dorgan ${ }^{1,2}$, Brian Dzwonkowski ${ }^{1,2}$

6

$7 \quad{ }^{1}$ Dauphin Island Sea Lab, Dauphin Island, AL 36528, USA

8 2Department of Marine Sciences, University of South Alabama, Mobile, AL 36608, USA

9

10 Corresponding Author:

11 Kara Gadeken ${ }^{1,2}$

12101 Bienville Blvd, Dauphin Island, AL, 36528, USA

13 Email address: kgadeken@disl.org

14

15

16

17

18

19

20

21

22 


\section{ABSTRACT}

25

The benthic impact of aquaculture waste depends on the area and extent of waste accumulation on the sediment surface below and around the farm. In this study we investigated the effect of flow on biodeposit transport and initial deposition by calculating a rough aquaculture "footprint" around an oyster aquaculture farm in the Damariscotta River, ME. We also compared a site under the farm to a downstream "away" site calculated to be within the footprint of the farm. We found similar sediment biogeochemical fluxes, geochemical properties and macrofaunal communities at the site under the farm and the away site, as well as low organic enrichment at both sites, indicating that biodeposition in this environment likely does not have a major influence on the benthos. To predict accumulation of biodeposits, we measured sediment erodibility under a range of shear stresses and found slightly higher erosion rates at the farm than at the away site. A microalgal mat was observed at the sediment surface in many sediment cores. Partial failure of the microalgal mat was observed at high shear velocity, suggesting that the mat may fail and surface sediment erode at shear velocities comparable to or greater than those calculated from in situ flow measurements. However, this study took place during neap tide, and it is likely that peak bottom velocities during spring tides are high enough to periodically "clear" under-farm sediment of recent deposits.

\section{INTRODUCTION}

As demand increases to feed the world's growing population, many are looking toward dramatically expanding marine aquaculture as an efficient and sustainable means of food production (Kobayashi et al., 2015; Gentry et al., 2017). Growth of the aquaculture industry seems to be rising to meet that demand; worldwide animal aquaculture production increased 
47 from less than 20 million tons in the early 1990s to $\sim 80$ million tons in 2016 and is rapidly

48 approaching parity with rates of wild seafood capture (FAO 2018). As aquaculture production

49 increases and more marine aquaculture operations open in coastal areas, the need for an

50 understanding of the local impacts of aquaculture grows more pressing, particularly of the under-

51 farm sediment environments receiving sinking aquaculture waste.

52 Past reports of the local benthic impact of aquaculture range from dramatic alteration of

53 bottom characteristics to apparently few effects depending on the cultured organism, the method

54 of culture and local environmental conditions (Kaiser et al., 1998; Newell et al., 2004; Forrest et

55 al., 2009). The impacts of aquaculture are commonly assessed by comparing sediment

56 characteristics and communities directly under an aquaculture farm to a less impacted or

57 reference site (Grant et al., 1995; Findlay \& Watling, 1997; Mallet et al., 2006; Higgins et al.,

582013 and others). However, the deposition of aquaculture biodeposits, and therefore their

59 eventual impact, depends on the physical drivers that transport the biodeposits to the benthos.

60 Direct measurements of particle sinking rate and horizontal distance traveled are lacking in the

61 literature (Callier et al., 2006), although several studies have numerically modeled them (Dowd,

62 2005; Navas et al., 2011; Comeau et al., 2014; Silva et al., 2019). Also sparse are descriptions of

63 post-deposition sediment dynamics; depending on the local flow environment, settling particles

64 that reach the benthos may remain there or be removed by erosion.

65 The footprint of an aquaculture farm is determined by the intensity of lateral flow and

66 settling rate of the particles. In areas with low flow, biodeposits would be expected to

67 accumulate under the farm, increasing the organic content and driving high influxes of oxygen

68 and effluxes of nutrients as organic matter is degraded (Forrest et al., 2009). Higher flow rates

69 may be expected to increase the transport distance and therefore the overall size of the farm 
70 footprint, likely resulting in a gradient of impact with distance from the farm. However, very

71 high flow may erode under-farm sediments and transport biodeposits a considerable distance

72 from the farm, smearing the edges of the footprint or clearing it completely. Thus the "footprint"

73 does not have a discrete value, but rather needs to be defined explicitly from the range of particle

74 sizes and flow velocities in the system. In tidal systems, erosion may only occur periodically

75 during ebb and flood tides when flow velocities peak or even episodically during peak spring

76 tides. If sediments are resuspended or fluidized, they are exposed to more oxygen, increasing

77 remineralization rates and depleting their labile organic content compared to surface sediments

78 (Aller, 2004). Thus, erosion and redeposition of biodeposits may reduce the effect of organic

79 enrichment even more than predicted by transport alone. This study aims to characterize the

80 footprint around an aquaculture farm, specifically addressing the questions: (Q1) How far are

81 biodeposit particles expected to travel from an aquaculture farm before deposition? (Q2) Once

82 deposits have settled to the benthos, do they remain there or are they eroded away?

83 Impacts of aquaculture can be assessed from differences in the sediment environment

84 under the farm compared with outside of the footprint. Sediments within the footprint are

85 expected to be finer grained and more organic-rich because biodeposits tend to be comprised of

86 finer grained materials than bulk deposited sediment (Haven and Morales-Alamo, 1966).

87 Nutrient enrichment from biodeposits may also encourage growth of a microalgal or microbial

88 mat, increasing sediment surface chlorophyll $a$ (chl-a), binding surface sediments and altering

89 nutrient and oxygen fluxes (Mirto et al., 2000, Giles et al., 2006, Walker and Grant, 2009). When

90 deposition of biodeposits under an oyster farm results in substantial organic enrichment of

91 sediments, the composition of the macrofaunal community may be altered, though this may vary

92 depending on the local environment of the farm (Forrest et al., 2009). Organic enrichment and 
93 physical disturbance both tend to reduce the body size, abundance, and diversity of sediment

94 macrofauna (Pearson \& Rosenberg, 1978; Aller \& Stupakoff, 1996). Sediments with high

95 organic enrichment tend to host macrofaunal communities comprising hypoxia- and sulfide-

96 tolerant taxa (Pearson \& Rosenberg, 1978), whereas physical disturbances like sediment erosion,

97 resuspension, and resettlement favor highly mobile, near-surface-dwelling, deposit-feeding taxa

98 (Brenchley, 1981; Aller \& Stupakoff, 1996). Differences in the functional traits and life histories

99 of macrofauna may suggest the kind of disturbance under-farm sediments experience most

100 frequently.

101 The Damariscotta River Estuary, Maine, is an ideal system for this study, as it

102 experiences strong tidal currents (Garrett, 1972; Brooks, 2009). Mean flow rates throughout a

103 tidal cycle in a narrow section of the Damariscotta are $\sim 1.1 \mathrm{~m} \mathrm{~s}^{-1}$, with peak velocities far higher

104 (McAlice, 1977). Aquaculture in Maine estuaries is also quickly growing; the total value of

105 Maine oyster aquaculture rose from less than \$1 million in 2005 to nearly \$9.7 million in 2019

106 (State of Maine Department of Marine Resources,

107 https://www.maine.gov/dmr/aquaculture/data/index.html). Much of that increase is attributable

108 to expansion of aquaculture in the Damariscotta River, which alone constitutes approximately

109 two-thirds of the total oyster production in Maine and increased in harvest yield from $\sim 1.3$

110 million to 9.4 million oysters between 2005 and 2019. Despite the industry's rapid growth,

111 there is little existing research examining the impacts of oyster aquaculture on the local benthos.

112 Our objective was to describe the footprint of an oyster farm in the Damariscotta River, ME, and

113 assess our estimate of the footprint by comparing sediments at sites under the farm and

114 downriver of the farm but within the same depth and flow regime. 


\section{MATERIALS \& METHODS}

\section{Study area}

118 The Damariscotta is a narrow, partially mixed mesotidal estuary in the midcoast of

119 Maine. The study was conducted at Perkins Point, approximately $20 \mathrm{~km}$ from the mouth of the

120 Damariscotta River (44 00.016’ N, 69 32.650’ W), where a large oyster aquaculture operation is

121 located on a 24-acre $\left(\sim 97,000 \mathrm{~m}^{2}\right)$ lease (Mook Sea Farm, Fig. 1). Verbal permission to use the

122 site for the study was obtained from Bill Mook, owner/operator of Mook Sea Farm. Eastern

123 oysters (Crassostrea virginica) are grown at the farm in mesh bags held in rigid, rectangular

124 floating OysterGro ${ }^{\mathrm{TM}}$ cages that are strung together in rows. The farm sits above a sloping shoal

125 with a mean water depth ranging from $\sim 2-4 \mathrm{~m}$. We assessed our estimate of the footprint by

126 comparing a site directly underneath the oyster cages ("Farm" site) in the southern portion of the

127 farm with one downstream, $\sim 90 \mathrm{~m}$ south of the edge of the farm lease area ("Away" site). The

128 Away site location was constrained by the geomorphology of the river; because the river bends

129 and narrows downstream (Fig. 1), selecting a site farther than $\sim 90$ m would risk it being in an

130 area too hydrodynamically different from the Farm site for comparison. Instruments were

131 deployed on moorings at both sites to measure hydrographic properties, with sediment traps to

132 quantify sedimentation. Sediment cores were also collected at each site for evaluation of

133 sediment erodibility, geochemical characteristics, biogeochemical fluxes, and macrofaunal

134 community structure. While diving to collect the cores for this study, we observed benthic

135 microalgal mats in distinct patches of varying sizes (Fig. 2), though we did not discriminate

136 between areas with and without mats in our sampling.

138 Flow and deposition 
140 (Q1), flow velocity near the bottom was measured over a tidal cycle with an Acoustic Doppler

141 Velocimeter (ADV) and combined with laboratory measurements of particle settling velocities.

142 Here we define the footprint based on the settling velocity of the mean size of biodeposits and

143 the maximum distance transported over the tidal cycle during neap tide. Because mean water

144 column height varied from $\sim 2-4 \mathrm{~m}$ across the farm, calculations were done with the maximum

145 and minimum depths to provide a range. Thus, biodeposit particles smaller than the mean would

146 travel beyond our defined footprint under peak flow velocities, but the footprint would

147 encompass most of the tidal range in deposition. To demonstrate the effect of particle size on the

148 footprint, we also calculated transport distance for the $5^{\text {th }}$ and $95^{\text {th }}$ percentile of particle sizes.

149 The ADV was horizontally mounted to a metal tripod mooring deployed at the Farm site,

150 measuring velocity $(8 \mathrm{~Hz}) 37 \mathrm{~cm}$ above the bottom. An Onset HOBO dissolved oxygen (DO)

151 logger was also mounted to the mooring (50 $\mathrm{cm}$ above the bottom) to measure near-bottom DO

152 to determine whether low oxygen occurred that might affect biogeochemical fluxes or infauna. A

153 cinder block mooring was deployed at the Away site. Temperature and salinity measurements

154 were collected near-surface and at bottom at both sites to measure stratification. Water level at

155 the farm was measured by the pressure sensor on the ADV. Moorings were deployed for $\sim 23 \mathrm{~h}$

156 on August 2-3, capturing nearly two tidal cycles during a neap tidal period. Because the

157 experiment was conducted over a short time frame, hydrographic data for the entire summer

158 season was obtained from a Land/Ocean Biogeochemical Observatory (LOBO) surface mooring

$159 \sim 250 \mathrm{~m}$ southeast of the farm (part of the Sustainable Ecological Aquaculture Buoy Network;

160 http://maine.loboviz.com). 

sedimentation rates. The traps were made of $5.08 \mathrm{~cm}$ inner diameter PVC cylinders, $15 \mathrm{~cm}$ in

163 length, and capped on one end, following Gardner (1980). Traps on the bottom mooring at the

164 Farm site were diver-deployed and intended to measure a combination of biodeposits directly

165 from the farm as well as ambient deposition. The Away site traps were attached to the cinder

166 block mooring that was lowered to the bottom from the boat and were intended to measure the

167 ambient particle deposition without influence from the farm. The mooring was repositioned once

168 it was on the bottom which may have created a sediment plume that falsely inflated

169 sedimentation data at that site, so those data should be interpreted with caution. Additional traps

170 were attached directly to the underside of the oyster cages at the Farm site for a direct estimate of

171 in-situ particle production by the oysters without under-farm flow transporting the particles.

172 Comparison of these data to deposition at the bottom mooring took into account the area of the

173 farm occupied by gear ( $40 \%$ - obtained from the farm’s lease application). Six traps were

174 deployed during two 24-hr deployment periods separated by 5 days, during which the tidal range

175 varied by $\sim 0.5 \mathrm{~m}$. All traps were deployed and retrieved at high tide. At least one trap was lost

176 from each location during each deployment. During the first period, traps were deployed and

177 recovered from the Farm site $(n=4)$ and the cages $(n=5)$. During the second period, sediment

178 traps were deployed and recovered from the Away site $(n=5)$ and the cages $(n=5)$. After

179 collection, sediments were dried for $24 \mathrm{~h}$ at $60^{\circ} \mathrm{C}$ and weighed.

180 To measure biodeposit settling velocities, biodeposits were collected from adult, harvest-

181 size oysters held in a flow-through seawater system. Biodeposits were spread in a petri dish to

182 prevent particle aggregation, maintaining the size and cylindrical shape of freshly released

183 biodeposits observed in both the lab and field. Deposits were then pipetted into the middle of a 
$18437.8 \mathrm{~L}$ aquarium of seawater, at least $12 \mathrm{~cm}$ away from any wall to prevent wall effects. Videos

185 of their descent were recorded using a Nikon D5300 DSLR camera equipped with an AF-S

186 Micro NIKKOR 105 macro lens. It was not possible to distinguish between feces and

187 pseudofeces from the observations, and we did not describe the composition of the biodeposit

188 particles. The descents of 100 individual particles were recorded. Each particle's dimensions

189 (length and diameter of cylindrical particle) were measured in ImageJ and the and angle (normal

190 to vertical) and rate of descent tracked with the ImageJ MtrackJ plugin (Schnider et al., 2012;

191 Meijering et al., 2012). Settling velocity depends on density and particle surface area. The length

192 and width of each particle measured from the videos were used to calculate surface area using

193 the geometric formula for cylinder surface area. We were unable to measure the densities of

194 individual pellets, but density was calculated using a form of Stokes' settling equation

195 specifically modified for small cylinders (Komar, 1980),

196

(1) $\quad V_{t}=0.079 \frac{1}{\mu}\left(\rho_{p}-\rho_{w}\right) g L^{2}\left(\frac{L}{D}\right)^{-1.664}$

197 where $V_{t}$ is settling velocity, $\mu$ is the viscosity of the water, $\rho_{p}$ and $\rho_{w}$ are the densities of the

198 particle and water respectively, $g$ is acceleration due to gravity, $\mathrm{L}$ is particle length, and $\mathrm{D}$ is

199 particle diameter. Particle surface area and angle of descent were compared to settling velocity

200 using a multiple regression. Density was not included in this model, as it was calculated from the 201 settling velocity.

202 An estimate of biodeposit tidal transport $\left(L_{f}\right)$ was calculated as:

203

(2) $\quad L_{f}=\frac{u_{s}(t) h(t)}{w_{s}}$

using the bottom horizontal velocity $\left(u_{s}\right)$ measured with the ADV and the mean particle settling

205 velocity $\left(w_{s}\right)$ calculated from the lab observations. The height of the water column $(h(t))$, or

206 vertical distance traveled, and bottom horizontal velocity $\left(u_{s}(t)\right)$ changed depending on the time 
$207(t)$ in the tidal cycle. To provide an upper and lower bound on the potential biodeposit tidal

208 transport, calculations used the deepest and shallowest mean water depths at the farm ( 2 and 4

$209 \mathrm{~m})$. It should be noted that this calculation uses velocity measured with the ADV which is

210 assumed to be in the bottom boundary layer, so the transport distances should be viewed as

211 conservative estimates.

213 Erosion

214 To determine whether settled biodeposits were likely to be resuspended (Q2), we

215 calculated bottom shear velocity throughout the flood/ebb tidal cycle and conducted laboratory

216 erosion experiments across a similar range of bottom shear velocities.

217 We used the flow velocities measured by the ADV to calculate bottom shear velocity

218 throughout the tidal cycle via three indirect methods (logarithmic profile, covariance and

219 turbulent kinetic energy methods) as described by Kim et al. (2000) for high sampling rates ( $>5$

$220 \mathrm{~Hz}$ ). Multiple methods are commonly used and compared, as methods can be biased by local

221 conditions such as waves, stratification, and bedforms (e.g. Sherwood et al., 2006; Pieterse et al.,

222 2015). The logarithmic profile method assumes a logarithmic velocity profile using the von

223 Karman-Prandtl equation. The reliability of the estimates from this method is severely limited by

224 having only a single point velocity measurement. However, single point techniques have been

225 developed (Sherwood et al., 2006) and Kim et al.'s (2000) methodology was followed. The

226 covariance method requires the velocity measurements to be in the constant stress layer of the

227 bottom boundary (a reasonable assumption for the instrument depth and low water column

228 stratification, buoyancy frequency $\sim 0.004$ ) and uses turbulent fluctuations in the along-estuary

229 direction and vertical flow velocities to determine the bottom stress. The turbulent kinetic energy 
230 method assumes a linear relationship between turbulent kinetic energy and bottom stress. Bottom

231 shear stress $\left(\tau_{b}\right)$ from both of these methods is then linked to shear velocity as $\tau_{b}=\rho u_{*}^{2}$ where $\rho$

232 is water density and $u_{*}$ is shear velocity. As seen in other studies, all three methods produced

233 results with similar patterns, but peak magnitudes showed considerable differences (e.g. Kim et

234 al. 2000, Sherwood et al. 2006, Pieterse et al., 2015). Because the covariance method is less

235 affected by local conditions (e.g. stratification, bedforms; Sherwood et al., 2006) and the

236 relationship between the along-estuary velocity and shear velocity was well represented by a

237 quadratic fit $\left(u_{*}=0.27096 u_{s}^{2}+0.00089 u_{s}+0.00466, \mathrm{R}=0.93\right)$, we used that estimate for our

238 further analyses. The effects of waves on bed stress were not considered because of the short

239 fetch of the estuary.

240 We conducted laboratory erosion experiments using a custom-built Gust erosion chamber

241 to generate near-uniform bed shear (Gust \& Muller, 1997; Thomsen \& Gust, 2000; Tengberg et

242 al., 2004; U-GEMS Manual, Green Eyes, LLC, 2015). Triplicate $10 \mathrm{~cm}$ diameter sediment cores

243 were collected by divers from the Farm and Away sites and placed in a large holding tank with

244 flowing seawater from the Damariscotta River. All erosion tests were performed within $60 \mathrm{~h}$ of

245 collection. Each core was capped with the Gust chamber, and a rotating disc within the chamber

246 generated increasing levels of shear velocity $\left(0.30 \mathrm{~cm} \mathrm{~s}^{-1}, 0.95 \mathrm{~cm} \mathrm{~s}^{-1}, 1.34 \mathrm{~cm} \mathrm{~s}^{-1}, 2.01 \mathrm{~cm} \mathrm{~s}^{-1}\right.$,

$2472.32 \mathrm{~cm} \mathrm{~s}^{-1}$ ). Each shear velocity level was maintained for $20 \mathrm{~min}$ before increasing disc rotation

248 and flow rates. For each 20 min shear velocity level, water and eroded material were removed by

249 a pump at the center of the disc at $10 \mathrm{~cm}$ above the sediment surface and filtered through $47 \mathrm{~mm}$

250 Whatman GF/F filters (1.5 $\mu \mathrm{m}$ pore size). Effluent was replaced with the same seawater supplied

251 to the core holding tank, so suspended mass in the pre-erosion core overlying water and the

252 replacement water was likely similar. The lowest shear velocity, $0.30 \mathrm{~cm} \mathrm{~s}^{-1}$, was used as a 
253 flushing step and was not filtered for suspended sediment analysis (no resuspension was

254 observed at this low shear). Filters were then dried at $60{ }^{\circ} \mathrm{C}$ for $24 \mathrm{~h}$ and weighed to obtain

255 eroded sediment mass for each shear velocity level. One Away core was not used in the analysis

256 due to accidental introduction of a large nereid worm from an unrelated experiment in the

257 holding tank. Suspended sediment concentration, $C_{s}\left(\mathrm{~kg} \mathrm{~m}^{-3}\right)$, for each site at each velocity level

258 was calculated from the dry mass $(\mathrm{kg})$ of filtered sediment divided by the volume $\left(\mathrm{m}^{-3}\right)$ of water

259 filtered. $C_{s}$ was converted to eroded mass per area $\left(E ; \mathrm{kg} \mathrm{m}^{-2}\right)$ :

$260 \quad$ (3) $\quad E=\frac{C_{s} V_{c}}{A_{c}}$

261 where $V_{c}$ is chamber volume $\left(7.9 \times 10^{-4} \mathrm{~m}^{3}\right)$, and $A_{c}$ is sediment surface area within the core $(7.9$

$262 \times 10^{-3} \mathrm{~m}^{2}$ ). Due to small and unequal sample sizes, statistical comparisons between sites and

263 stress levels were not performed.

264 To generate specific shear velocities, cap rotation and pumping rate were set using

265 calibration equations from the University of Maryland Center of Environmental Science Gust

266 Erosion Microcosm System (U-GEMS) Manual (Green Eyes, LLC, 2015):

267

(4) $u_{15}^{*}=0.0318 n^{0.763}$

268

$$
Q=-28.31 u_{15}^{* 2}+170.2 u_{15}^{*}-23.85
$$

269 where $u^{*}{ }_{15}$ is shear velocity at $15^{\circ} \mathrm{C}\left(\mathrm{cm} \mathrm{s}^{-1}\right), n$ is rotations per minute, and $Q$ is pumping rate $270\left(\mathrm{~mL} \mathrm{~min}^{-1}\right)$. Shear velocity at $15^{\circ} \mathrm{C}$ was converted to shear velocity at the water temperature 271 measured during the erosion tests $\left(22^{\circ} \mathrm{C}\right)$ as:

$$
u_{15}^{*}=u_{22}^{*}[1+0.006(22-15)]
$$

273 where $u_{22}^{*}$ is shear velocity at $22^{\circ} \mathrm{C}\left(\mathrm{cm} \mathrm{s}^{-1}\right)$ (U-GEMS Manual, Green Eyes, LLC, 2015). For

274 those more familiar with stress as a measure of shear, the corresponding applied bottom shear 
275 stresses $\left(\tau_{b} ; \mathrm{Pa}\right)$ generated by the Gust chamber were 0.009 Pa, 0.09 Pa, 0.18 Pa, 0.41 Pa, and

$2760.55 \mathrm{~Pa}$. These were calculated from shear velocities $\left(u_{22}^{*} ; \mathrm{m} \mathrm{s}^{-1}\right)$ as:

$277 \quad(7) \quad \tau_{b}=\rho u_{22}^{* 2}$

278 (U-GEMS Manual, Green Eyes, LLC, 2015). A $\rho$ of $1021 \mathrm{~kg} \mathrm{~m}^{-3}$ was used based on an average 279 temperature of $22^{\circ} \mathrm{C}$ and salinity of $31 \mathrm{psu}$.

280 This field sampling occurred during neap tide, and also coincided with the highest surface

281 water temperatures of the year when thermal stratification likely peaked. To gain a broader sense

282 of the potential for sediment resuspension during other times in the tidal cycle, near-surface

283 turbidity and velocity data from the LOBO surface mooring east of the farm were analyzed for

284 longer-term patterns. While turbidity is not a direct measure of sediment resuspension, water

285 clarity is typically related to sediment concentrations. Potential relationships among

286 precipitation, water level, current velocity and turbidity were investigated using both the

287 instantaneous data and 40-hour low-pass filtered signals. Near-surface velocity data were also 288 used to estimate bottom shear velocities in higher-flow times in the spring-neap cycle. Near289 surface velocity was converted to a proxy for near-bottom velocity based on a scaling factor 290 determined from the relationship between the LOBO buoy and the ADV-measured velocities

291 during the overlap period in August. This near-bottom velocity proxy was used to estimate shear 292 velocity using a quadratic relationship between the longitudinal velocity and direct calculations 293 of the shear velocity (using the covariance method). This fitted relationship was extrapolated to 294 predict shear velocity expected from the highest flow in the spring-neap tidal cycle.

296 Geochemical characterization 
Sediments at both sites were evaluated for grain size distribution, water content, percent

298

299

300

301

302

303

304

305

306

307

308 organic content, and concentrations of $\mathrm{C}$ and $\mathrm{N}$. One diver-collected 10-cm diam core from each

site was vertically sectioned. Water content was calculated as the difference between wet and dry masses after sediment was dried at $60^{\circ} \mathrm{C}$ for $24 \mathrm{~h}$. Percent organic content was calculated as the difference between dry and ash masses after burning sediment at $500{ }^{\circ} \mathrm{C}$ for $4 \mathrm{~h}$. Burned sediment was then soaked in a $1 \%$ sodium metaphosphate dispersant solution for $24 \mathrm{~h}$ to rehydrate and disaggregate sediment prior to grain size analysis. Grain size distribution was determined using a Malvern Mastersizer 3000 particle analyzer (Malvern Panalytical, Malvern, UK). Data were analyzed using Gradistat (Kenneth Pye Associates, Ltd., Berkshire, UK).

Preparation of $\mathrm{C}$ and $\mathrm{N}$ samples included an acidification step to remove inorganic carbon. Concentrated $\mathrm{HCl}$ was added to dried sediment samples and heated at $80{ }^{\circ} \mathrm{C}$ until the fluid evaporated as described by U.S. EPA (2009). Acidified and non-acidified samples were analyzed for $\mathrm{C}: \mathrm{N}$ to determine the proportion of inorganic carbon. $\mathrm{C}$ and $\mathrm{N}$ were analyzed on a CHNSO elemental combustion system analyzer (mod. ECS 4010; Costech Analytical Technologies, Valencia, CA). C:N is reported as a molar ratio ( $\mathrm{mmol} \mathrm{g}^{-1}$ sediment).

\section{Biogeochemical fluxes}

To determine whether the "Away" site exhibited similar impacts of oyster biodeposits on biogeochemical fluxes as the site directly under the farm, sediment core incubations were performed in the dark to measure nutrient, DIC and oxygen fluxes and sediment surface samples were collected for chlorophyll a (chl-a) analysis. In an additional treatment, "Amended" cores, we added oyster feces and pseudofeces onto the top of two cores from the "Away" site. Because of the lack of available data for this area on typical respiration rates, the Amended treatment was 
320 included to determine whether Away site sediments were being enriched with biodeposits; if

321 sediments from the Away site were receiving large influx of organic matter from the farm, i.e.,

322 were saturated, additional organic matter would be expected to have minimal effect on nutrient

323 and oxygen fluxes. The usefulness of the Amended cores therefore depended on "background"

324 (i.e., unenriched) respiration rates being relatively low.

325 Incubations of sediment cores were performed to measure sediment oxygen flux and

326 nutrient $\left(\mathrm{NH}_{4}{ }^{+}\right.$and $\left.\mathrm{PO}_{4}{ }^{3-}\right)$ and dissolved inorganic carbon (DIC) fluxes. Only dark incubations

327 were performed so that maximum respiration rates could be measured without the influence of

328 microalgal photosynthesis. Our measurements are therefore not representative of daytime in situ

329 fluxes. A total of 12 15.2-cm diam sediment cores were taken by divers during two collections (2

330 and 7 August 2018). During each collection, two cores were taken from the Farm site and four

331 were taken from the Away site. Care was taken during collection that each core had at least 10

$332 \mathrm{~cm}$ of sediment depth and at least $4 \mathrm{~cm}$ of overlying water. The cores were brought back to the

333 lab and kept in tanks with flowing water from the Damariscotta River until use in the incubations

334 ( $<36 \mathrm{~h}$ post-collection). Immediately before the start of the incubations, $8 \mathrm{~mL}$ wet volume of

335 oyster feces and pseudofeces were pipetted onto the top of two cores collected from the Away

336 site and designated the Amended cores. Between the two samplings, this resulted in a total of

337 four replicates each of Farm, Away and Amended cores.

338 In incubations, the cores were each submerged in separate 5-gallon buckets of seawater

339 and watertight caps affixed to the tops (after methods and Fig. 2 in Dorgan et al., 2020). The caps

340 allowed for $6 \mathrm{~cm}$ of overlying water and were each equipped with a stir-bar to gently circulate

341 the overlying water, inflow and outflow taps for water sampling, and an Atlas Scientific DO

342 probe (Atlas Scientific LLC, Long Island City, NY) that measured oxygen concentrations in the 
343 overlying water of each core every $\sim 12 \mathrm{~s}$. The buckets containing the cores were covered with

344 foil to prevent oxygen production by photosynthesis from corrupting oxygen consumption rate

345 measurements. The incubations of cores collected on 2 August provided simultaneous oxygen,

346 nutrient and DIC fluxes. Nutrient and DIC samples were gathered during the incubation of the 7

347 August cores, however the oxygen measurement instrument failed to record during the initial

348 incubation, so a second incubation was done on the same cores the following day to collect data

349 to calculate oxygen flux. Sediment samples for chl-a were taken from the top $\sim 1 \mathrm{~cm}$ of the cores

350 following the second incubation and frozen for later analysis. The samples were prepared using

351 methods adapted from Welschmeyer (1994) and analyzed on a Turner Trilogy 7200 using an

$352 \mathrm{HCl}$ acidification step to measure chl-a and phaeopigment concentrations.

353 Nutrient and DIC samples were siphoned from overlying core water at three timepoints

354 using methods described by Lehrter et al. (2012). Samples were taken at the start ( 0 hrs elapsed),

355 middle ( 2 hrs elapsed) and end (4 hrs elapsed) of the incubations. DIC samples were kept dark

356 and cold in $20 \mathrm{~mL}$ glass vials until processed $(<24 \mathrm{~h}$ post-collection) on a TOC Carbon analyzer.

357 Nutrient samples were filtered through $25 \mathrm{~mm}$ Whatman GF/F filters ( $0.7 \mathrm{um}$ pore size) and

358 frozen in the dark until processed for $\mathrm{NH}_{4}{ }^{+}$and $\mathrm{PO}_{4}{ }^{3-}$ at the Dauphin Island Sea $\mathrm{Lab} . \mathrm{NH}_{4}{ }^{+}$was

359 measured fluorometrically with modifications as described by Yates et al. (2015) and Holmes et

360 al. (1999). $\mathrm{PO}_{4}{ }^{3-}$ was measured on a spectrophotometer with slight modifications from methods

361 described in Grasshoff et al. (1983). Rates of change in overlying water concentration for

362 oxygen, DIC and each nutrient were calculated from the linear regression of the respective

363 analyte concentrations versus time. These rates of change $\left(\mathrm{mmol} \mathrm{min}^{-1}\right)$ were multiplied by the

364 height of overlying water to obtain flux rates $\left(\mathrm{mmol} \mathrm{m}^{-2} \mathrm{~d}^{-1}\right)$. We were unable to obtain oxygen

365 flux values for the Amended cores because they lacked a consistent oxygen trend. Some cores 
366 produced several successive oxygen slopes within the same range of oxygen concentrations

367 because low-oxygen water was replaced with high oxygen water during the sampling for

368 nutrients. To calculate a single oxygen flux for each of these cores, time-weighted average slopes

369 were calculated. Shapiro-Wilk and Kruskal-Wallis tests were performed on nutrient and oxygen

370 flux data to determine if there were differences in fluxes between sites.

371

372 Macrofaunal community structure

After data collection, all incubation cores were sieved $(500 \mu \mathrm{m})$ and the remaining material preserved in 95\% ethanol and rose Bengal stain. Macrofauna were picked out of each sample, and individuals identified to family level. Statistical comparison of abundances between the two sites was not performed due to small and uneven sample size. Data from replicate cores were analyzed for Shannon diversity (H') and Pielou's evenness (J'), averaged by site, then student t-tests were performed on the diversity and evenness metrics to compare the two sites. An NMDS analysis was performed on square-root transformed data (to decrease weighting of highly abundant groups) to compare community structure between sites (PRIMER v7, PRIMER-

381 E Ltd, Plymouth).

382

\section{RESULTS}

\section{Flow and deposition}

The velocity data were strongly tidal during the deployment, with a clear semi-diurnal

cycle. The water level had a $2.86 \mathrm{~m}$ range, with a mean water depth of $3.4 \mathrm{~m}$ at the away site and

$3.5 \mathrm{~m}$ at the farm site. The ADV measured near-bottom velocities ranging $\pm 20 \mathrm{~cm} \mathrm{~s}^{-1}$ (Fig. 3A). 
389 in duration, with flood tide being $~ 1.9$ times longer than ebb. Bottom dissolved oxygen remained

390 above $8 \mathrm{mg} \mathrm{L}^{-1}$ throughout the sampling period (data not plotted).

391 The rate of deposition calculated from sediment traps attached to the bottom mooring

392 beneath the farm was $\left(490 \pm 36 \mathrm{~g} \mathrm{~m}^{-2} \mathrm{~d}^{-1}, \mathrm{n}=4\right)$. The cage-area normalized rates of deposition

393 calculated from the traps attached to the cages were $\left(163 \pm 86 \mathrm{~g} \mathrm{~m}^{-2} \mathrm{~d}^{-1}, \mathrm{n}=5\right)$ for the first

394 deployment and $\left(230 \pm 132 \mathrm{~g} \mathrm{~m}^{-2} \mathrm{~d}^{-1}, \mathrm{n}=5\right)$ for the second. These rates were calculated by

395 multiplying the deposition rate calculated from the beneath-cage traps by the percent area of the

396 farm occupied by gear (40\%), following the methods of Testa et al. (2015). The highest

397 deposition rate was at the Away site $\left(892 \pm 87 \mathrm{~g} \mathrm{~m}^{-2} \mathrm{~d}^{-1}, \mathrm{n}=5\right)$, where deployment and

398 repositioning of the cinder block mooring may have resuspended sediments.

399 The biodeposits were cylindrical in shape, with an average length of $0.64 \pm 0.14 \mathrm{~mm}$ and

400 average diameter of $0.11 \pm 0.02 \mathrm{~mm}$. Biodeposit surface area ranged from $0.12 \mathrm{~mm}^{2}$ to $0.60 \mathrm{~mm}^{2}$

401 with an average surface area of $0.25 \pm 0.09 \mathrm{~mm}^{2}$. For each $1 \mathrm{~mm}^{2}$ increase in surface area, we

402 observed a $0.57( \pm 0.53 ; \pm 95 \% \mathrm{CI}) \mathrm{cm} \mathrm{s}^{-1}$ increase in settling velocity $\left(\mathrm{p}=0.03 ; \mathrm{r}^{2}=0.03\right)$ (Fig. 4).

403 The angle of descent did not significantly affect the settling velocity of biodeposits $(\mathrm{p}=0.72)$.

404 Using the modified Stokes equation, mean pellet density was calculated to be $1.42 \pm 0.18 \mathrm{~g} \mathrm{~cm}^{-3}$

405 with a range of 1.13 to $2.26 \mathrm{~g} \mathrm{~cm}^{-3}$.

406 To simplify calculations of horizontal particle transport, settling velocity was averaged

407 across all particle sizes as $0.73 \pm 0.23 \mathrm{~cm} \mathrm{~s}^{-1}$. At this velocity, a particle would take $\sim 5-10$ min

408 from release to deposition across the range of typical site depths (2-4 m). Oyster biodeposits had

409 a mean tidal transport range of $72 \mathrm{~m}$ upstream at peak flood and $62 \mathrm{~m}$ downstream at peak ebb in

410 the shallow (2m depth) section of the farm (Fig. 3B) and $118 \mathrm{~m}$ both upstream and downstream

411 in the deep (4m depth) section of the farm (Fig. 3C). 
412

\section{Erosion}

414 Bottom shear velocities generated by the Gust chamber were in the range of those

415 calculated from the bottom velocities measured by the ADV (Fig. 5A). Shear velocity from the

416 covariance estimate ranged from $0.27 \mathrm{~cm} \mathrm{~s}^{-1}$ during slack tide to $1.7 \mathrm{~cm} \mathrm{~s}^{-1}$ at max ebb and flood.

417 The lowest shear velocity tested in the erodibility experiments $\left(0.95 \mathrm{~cm} \mathrm{~s}^{-1}\right)$ was within this

418 range, and the higher shear velocities tested extended above the maximum field observations,

419 with values up to $2.32 \mathrm{~cm} \mathrm{~s}^{-1}$ (Fig. 5A, Fig. 6). There appeared to be more eroded mass at a given

420 shear velocity under the farm than away and average total cumulative eroded mass under the

421 farm $\left(6.82 \pm 2.52 \mathrm{~g} \mathrm{~m}^{-2}\right)$ was over twice as high as that away from the farm $\left(3.22 \pm 0.34 \mathrm{~g} \mathrm{~m}^{-2}\right)$.

422 Additionally, eroded mass appeared to increase more with increasing shear velocity at the Farm

423 than at the Away site, but only at the highest shear velocity did error bars not overlap between

424 the two sites (Fig. 6).

425 There was visible evidence of erosion that was not quantified by the erosion chamber.

426 Cohesive microbial mats were observed on the sediment surface in most erosion cores, and much

427 of the eroded material was composed of larger particles or aggregates that were not entrained

428 high enough in the erosion chamber to be taken up in the effluent and quantified by filtration.

429 During the $2.01 \mathrm{~cm} \mathrm{~s}^{-1}$ period of one Farm replicate, dislodged aggregates formed a mound in the 430 center of the core (Fig. 5B). Partial mat failure was observed in the $2.32 \mathrm{~cm} \mathrm{~s}^{-1}$ period of one

431 Away replicate (Fig. 5C).

432 Longer-term data from the nearby LOBO buoy show that surface velocities under spring

433 tidal conditions were nearly twice as high as during the period of the field sampling (Fig. 7). The

434 scaling factor used to estimate bottom velocity from the relationship between the surface LOBO 
435 buoy and bottom $\mathrm{ADV}$ was 1.40 and showed a good fit $(\mathrm{R}=0.95)$. Using the scaling factor,

436 bottom velocities during spring tides were estimated as $\sim 30 \mathrm{~cm} \mathrm{~s}^{-1}$ during ebb and $\sim 25 \mathrm{~cm} \mathrm{~s}^{-1}$

437 during flood, with the maximum at $\sim 40 \mathrm{~cm} \mathrm{~s}^{-1}$. Neap tide bottom velocities were $\sim 20 \mathrm{~cm} \mathrm{~s}^{-1}$

438 during both ebb and flood, corresponding well with the bottom velocities measured by the ADV.

439 During the spring tides, the calculated shear velocity approached $3 \mathrm{~cm} \mathrm{~s}^{-1}$, higher than the highest

440 shear velocities tested in the erosion tests or encountered during the experiment (Fig. 5A). The

441 long-term data also show that peak velocities were often associated with high turbidity events

442 (Fig. 7). It should be noted that some of the high turbidity events were also associated with large

443 precipitation events (triangles in Fig. 7), thus were likely driven by sediment runoff rather than 444 resuspension.

\section{Geochemical characterization and biogeochemical fluxes}

Sediments at both sites were poorly sorted coarse silt to fine sand (Fig. 8A, Table S1)

448 (Folk \& Ward, 1957). Organic content and water content were higher in muddier sediments as

expected, and muddiness increased with depth at the Away site but varied with depth at the Farm

450 site (Fig. 8, Table S1). The C:N (mmol g${ }^{-1}$ sediment) was 11.2 at the Away site and 11.48 at the

451 Farm site (Table S1). Surface sediment chl-a measurements from Farm sediments were 14.3 and

$452 \quad 11.8 \mu \mathrm{g}$ chl-a g ${ }^{-1}$ dry sediment and Away sediments were 7.3 and $22.5 \mu \mathrm{g}$ chl-a g ${ }^{-1}$ dry sediment.

453 Phaeopigment concentrations were lower than chl-a in both samples from both the Farm site

454 (5.88 and $6.80 \mu \mathrm{g} \mathrm{g}^{-1}$ dry sediment) and Away site (11.05 and $8.74 \mu \mathrm{g} \mathrm{g}^{-1}$ dry sediment).

455 Replication was not high enough to test if measurements of sediment fluxes differed

456 between the two incubations, so data from both incubations were pooled by treatment (Away,

457 Farm, and Away Amended, $\mathrm{n}=4$ for each treatment, Table S2). Sediment oxygen flux did not 
458 differ between the Farm and the Away sites, with negative values indicating flux into the

459 sediment (Mann-Whitney Wilcoxon $\mathrm{p}=0.69)($ Fig. 9A). DIC fluxes out of the sediment did not

460 differ among treatments (Kruskall-Wallis $\mathrm{p}=0.66$ ) but were highly variable, especially among

461 the Away cores (Fig. 9B). $\mathrm{NH}_{4}{ }^{+}$and $\mathrm{PO}_{4}{ }^{3-}$ fluxes were similar among all treatments (Kruskall-

462 Wallis $p=0.79$ and 0.31 , respectively) (Fig. 9C, D). There was no relationship between fluxes of

$463 \mathrm{O}_{2}$ and DIC $(\mathrm{p}=0.36), \mathrm{NH}_{4}{ }^{+}(\mathrm{p}=0.44)$ or $\mathrm{PO}_{4}{ }^{3-}(\mathrm{p}=0.51)($ Fig. 9C, $\mathrm{E}, \mathrm{G})$.

464 A large nereid worm was found in a core taken from directly underneath the farm. This

465 core also had the highest oxygen flux of all cores measured $\left(-72.5 \mathrm{mmol} \mathrm{m}^{-2} \mathrm{~d}^{-1}\right)$. A large

466 nephtyid worm was found in an Away core that had the next highest oxygen flux measured (-

$\left.46760.6 \mathrm{mmol} \mathrm{m}^{-2} \mathrm{~d}^{-1}\right)$. Removing these two cores from the sediment flux analyses did not result in

468 significant differences among treatments (all $p>0.1$ ) or significant relationships between

469 nutrients and oxygen flux (all $\mathrm{p}>0.45$ ).

470

471 Macrofaunal community structure

472

Twelve families of macrofauna in 3 phyla were found among all samples collected (Fig.

473 10A, Table S3). Overall, macrofauna present at both sites were small-bodied and mainly

474 consisted of burrowing, suspension-feeding bivalves (e.g., Myidae, Mactridae), surface deposit-

475 feeding polychaetes (e.g., Spionidae, Flabelligeridae) and the burrowing, carnivorous polychaete,

476 Nephtyidae. Abundance and taxa richness were highly variable at both sites. Family richness did

477 not appear to differ between the sites, with $3.25 \pm 1.89$ families (mean \pm st. dev.) at the Farm site

478 and $4.0 \pm 2.0$ families at the Away site. Abundance appeared to be higher at the Away site, with

$4793411 \pm 3902$ individuals $\mathrm{m}^{-2}$, compared to $459 \pm 397$ individuals $\mathrm{m}^{-2}$ at the Farm site, but

480 variability was high with the abundance of most families having a greater standard deviation than 
481 the mean (Fig. 10A, Table S3). Abundance was low in all macrofaunal groups except for small

482 nephtyid polychaetes which dominated at the Away site, making up $88 \%$ of the abundance.

483 Shannon diversity also appeared similar but variable, with $H^{\prime}=0.85 \pm 0.22$ at the Farm site and

$484 \mathrm{H}^{\prime}=0.71 \pm 0.60$ at the Away site (Student's t-test, $\left.\mathrm{p}=0.59\right)$. Pielou's evenness $\left(\mathrm{J}^{\prime}\right)$ at the Farm

485 site was $0.86 \pm 0.18$ and at the Away site was $0.54 \pm 0.36$ and was not significantly different

486 between sites (Student's t-test, $\mathrm{p}=0.08$ ). There was no distinct partitioning in community

487 structure between Farm and Away samples, although several of the Away site samples that

488 shared relatively high abundance $\left(>6000 \mathrm{~m}^{-2}\right)$ of nephtyids were $>60 \%$ similar (bold circle in

489 Fig. 10B).

490

491 DISCUSSION

492 Farm footprint

493 The near-bottom velocities at the study site during the study period and lab measurements

494 of biodeposit settlement rates were used to calculate a rough "footprint" of the impact of the farm

495 on the sediment. An average-sized biodeposit released in the deeper section of the farm likely

496 settled at a maximum of $118 \mathrm{~m}$ up or downstream of the farm at peak tidal flows, and far less if it

497 was released in the shallower part of the farm (Fig. 3). At peak flow the smallest biodeposits in

498 the deep section of the farm could have traveled up to $200 \mathrm{~m}$ from the farm before deposition,

499 however transport of particles in the shallow section was more constrained (Fig. 3B), indicating

500 that most particles would be settling within a far smaller range. Based on our footprint

501 estimation, our selected Away site at $\sim 90 \mathrm{~m}$ downstream falls within the footprint of the farm

502 and would therefore be expected to regularly but not continually receive oyster biodeposits. 
504 our mean rate of $0.73 \mathrm{~cm} \mathrm{~s}^{-1}$ used in the "footprint" calculation is similar to previous

505 measurements of $\sim 0.8 \mathrm{~cm} \mathrm{~s}^{-1}$ (Haven et al., 1972) and, unlike previous investigations, was

506 measured using biodeposits from the system of study. Our estimate of settling velocity is

507 conservative, as it assumes biodeposits are sinking unaggregated. In situ, biodeposits may

508 aggregate together, increasing settling velocity and reducing the farm's "footprint".

509 The weak correlation between settling velocity and surface area (Fig. 4) in addition to the

510 non-zero intercept (we would expect particles with a surface area of $0 \mathrm{~mm}^{2}$ to have a settling

511 velocity of $0 \mathrm{~cm} \mathrm{~s}^{-1}$ ) illustrates that either the relationship between surface area and settling

512 velocity is nonlinear near zero, or that other parameters such as biodeposit density vary in a non-

513 random way. We hypothesize that the scatter of data and the related poor fit likely results from

514 differences in density among biodeposits, specifically that smaller biodeposits settle relatively

515 faster because they are more dense than larger biodeposits. Oysters separate labile organic matter

516 from refractory material and nonorganic material like sand and excrete these materials in feces

517 and psuedofeces, respectively (Haven and Morales-Alamo, 1966). Biodeposits at the lower end

518 of our range of densities $\left(1.14 \mathrm{~g} \mathrm{~cm}^{-3}\right)$ are likely composed primarily of organic matter, while

519 those at the upper end $\left(2.26 \mathrm{~g} \mathrm{~cm}^{-3}\right)$ likely consist primarily of nonorganic minerals. Presumably,

520 the relative makeup of these deposits depends on the composition of the suspended material in

521 the water column at the time of filtration, affecting the densities of both feces and pseudofeces.

522 We were unable to differentiate between feces and pseudofeces in this study, and did not

523 measure the density of individual pellets, preventing stronger correlations between biodeposit

524 characteristics and settling velocity. 
526 velocities, and larger bivalves tend to produce more biodeposits than smaller ones (Haven et al.,

527 1972). It is therefore important to consider the species and the size of bivalves when estimating

528 the area of impact. For example, Callier et al. (2006) found that settling velocities for marine

529 mussel biodeposits ranged from $\sim 0.3-1.8 \mathrm{~cm} \mathrm{~s}^{-1}$ and varied based on the size of the individual.

530 These higher settling velocities would result in an area of impact smaller than that calculated

531 here based on oyster biodeposits, which may lead to greater rates of accumulation, particularly if

532 individual bivalves were larger and produced more biodeposits. We did not account for

533 individual size in this study, which could have been a source of variability in both the mean

534 settling velocity and mean deposition rate.

535 Cage-area normalized rates of deposition ranged from roughly one third to one half of the 536 deposition rates measured at the bottom mooring underneath the farm, suggesting that particle

537 deposition beneath the farm consists of more than just oyster biodeposits. While all our

538 deposition rates were within the range of other literature values, $\sim 10-650 \mathrm{~g} \mathrm{~m}^{-2} \mathrm{~d}^{-1}$ (Comeau et

539 al., 2014), oyster biodeposition rates can vary widely with season (Comeau et al., 2014) and

540 oyster size (Haven et al., 1972), so direct comparisons between farms should be done with that in

541 mind. Deposition at the Away site was particularly high, however in hindsight we suspect this

542 may have been an artifact of the deployment method; the Away mooring was lowered to the

543 bottom from the boat and was repositioned after deployment, which may have created a sediment

544 plume that inflated settlement trap data. We also found that our Away site fell within the

545 deposition footprint of the farm, leaving us unable to parse the relative impact of farm-sourced

546 biodeposits and ambient particle deposition on total particle flux. 


\section{Site comparison}

549 The lack of difference in biogeochemical fluxes and macrofaunal community structure

550 between the Farm and Away sites and the relatively low organic matter content indicate that

551 biodeposition is not a major influence at either site, i.e., that regardless of whether the Away site

552 was within the footprint of the farm, deposition was small enough to have minimal impact.

553 Previous studies in other systems have generally found significant differences in biogeochemical

554 fluxes between farm and references sites, however reference sites in these studies tend to be

$555>500 \mathrm{~m}$ away from farm sites (Testa et al., 2015; Richard et al., 2007; Giles et al., 2006),

556 considerably further than the Away site in this study, which was selected at only $\sim 90 \mathrm{~m}$ from the

557 edge of the farm lease to avoid the flow effects of the constriction in the river downstream. A

558 similar reference site distance was selected by Mallet et al (2006) in a study of an oyster farm in

559 New Brunswick, Canada. There, the researchers also found no difference between sediment

560 geochemistry at reference and farm sites. Additionally, any potential difference in fluxes

561 between our two sites may have been obscured by high within-site variability (Fig. 9). Callier et

562 al. (2009) also found trends, but no significant differences, in biogeochemical fluxes between

563 "unimpacted" reference cores and cores with increasing densities of mussels suspended above

564 them to simulate farm deposition, with high variability within their core treatments.

565 Like the variability in erosion, microalgal aggregations on the sediment surface may have

566 contributed to variability in fluxes. Microphytobenthos have been shown in several studies to

567 regulate biogeochemical fluxes across the sediment-water interface (Reay et al., 1995, Cerco \&

568 Seitzinger 1997), even when cores are kept in the dark (Sundbäck \& Granéli 1988). Indeed, chl-a

569 measurements from the incubation cores (7.3-22.5 $\mu \mathrm{g} \mathrm{g}^{-1}$ dry sediment) were higher than the

570 highest measured by Watling et al. (2001) (5.24 $\mu \mathrm{g} \mathrm{g}^{-1}$ dry sediment) in sediments from a deeper 
571 area of the Damariscotta. Chl-a concentrations were also higher than concentrations of

572 phaeopigments (which indicate degraded chlorophyll often due to grazing), implying abundant

573 living microphytobenthos (e.g., Bianchi et al., 1988). Chl-a was highly variable between

574 samples, suggesting patchiness that may have contributed to variation in fluxes.

575

Although there was not a correlation between oxygen flux and DIC (Fig. 9), the ratio of

576 DIC flux to $\mathrm{O}_{2}$ flux was $\sim 2$, higher than predicted from stoichiometry and observed in high-

577 Arctic sediments (Rysgaard et al., 1998), but similar to other studies in sediments under

578 normoxic conditions and lower than in hypoxic sediments (Lehrter et al., 2012; An \& Joye

579 2001). This is also in line with a previous study by Newell et al. 2002 on the influence of

580 biodeposition on sediments. They performed dark incubations of biodeposit-enriched sediment

581 cores with a microalgal mat and found low oxygen influxes relative to DIC efflux, attributing the

582 skewed ratio to the diversion of oxygen into oxidizing reduced compounds (Newell et al., 2002).

583 The "Amended" cores that were enriched with biodeposits prior to incubation showed no

584 differences in nutrient fluxes from unenriched Away site cores, which suggests that these

585 sediments were already saturated with organic matter. The amount of biodeposits added was

586 comparable to the deposition at the farm site over a day $\left(8 \mathrm{~mL} \times 1.4 \mathrm{~g} \mathrm{~mL}^{-1}\right.$ density of

587 biodeposits spread over the area of a $15 \mathrm{~cm}$ diam core is $634 \mathrm{~g} \mathrm{~m}^{-2}$; assuming the biodeposits

588 were loosely packed, this would be an overestimate, so the actual amount added is closer to the

$589490 \mathrm{~g} \mathrm{~m}^{-2} \mathrm{~d}^{-1}$ collected in sediment traps under the farm). However, it is important to note that,

590 because of the incubation equipment malfunction, the oxygen flux measurements and nutrient

591 sample collections for the second set of cores did not occur simultaneously, so conclusions about

592 the relationship between oxygen and nutrient fluxes should be drawn with caution. 
594 biodeposition is minimal. Surprisingly, sediment at the Away site appeared to be slightly

595 muddier and have higher organic content than the Farm site (Fig. 8). While we expected

596 sediments at the Farm site to be finer and have higher organic content because of increased

597 biodeposition, the potential addition of larger particles from eroding oyster shell to sediment

598 directly beneath the oyster cages could coarsen the sediment and dilute its organic content with

599 large and mostly inorganic shell fragments. However, it is difficult to assess site differences from

600 these data given only one core was taken from each site.

601 The Away and Farm sites had similar infaunal communities, except for the abundant

602 small nephtyids in some of the Away cores. It is likely that these were juveniles, and the

603 differences in abundance due to patchy recruitment. There is a general absence of recent infaunal

604 community data from this area of the Damariscotta, which makes it difficult to assess from the

605 literature whether the communities at and around the farm are comparable to other locations in

606 the estuary. Additionally, macrofaunal abundance and community assemblage appear very

607 patchy in these sediments and were probably not fully described by our sampling. Also, the cores

608 were stored in a tank with sediment containing large macrofauna from an unrelated experiment,

609 so it is possible that the large nereid and nephtyid worms found when samples were sorted had

610 migrated and established in our cores and were not representative of the natural community at

611 our sites. However, many large nereid jaws were observed in the bulk material while samples

612 were being sorted, as well as many juvenile nephtyids counted, which suggests that the large

613 macrofauna were likely present in the cores when they were collected.

614 Other than the abundant, small nephtyids at the Away site, the macrofaunal assemblages

615 at both Farm and Away sites mainly consisted of discretely-motile, surface deposit/suspension 
616 feeding polychaetes (spionids and flabelligerids) and suspension-feeding infaunal bivalves

617 (myids, mactrids, and pharids). Relative dominance of suspension feeders suggests that flow is

618 slow enough to avoid sediment destabilization but fast enough to maintain sufficient suspended

619 food particle flux (e.g., Widdows et al., 2004). Additionally, surface-deposit feeding may be

620 particularly advantageous where an algal biofilm offers a concentrated high-quality food source

621 at the sediment surface (Decho and Lopez, 1993; Montserrat et al., 2008). Such mats, however,

622 may disadvantage subsurface deposit feeders by impeding sediment-water exchange of oxygen

623 and reduced compounds (e.g., Hansen \& Kristensen, 1997). Subsurface deposit feeders

624 contributed less than $20 \%$ to Farm and Away total abundance, excluding nephtyid abundance.

625 Though our sampling occurred during a relatively quiescent period of low flow and turbidity, the 626 spring tide several weeks prior (Fig. 7) would have produced high flow rates and sediment 627 erosion potentially stressful for infauna.

628

629 Potential flushing of biodeposits

630 The partial mat failure during the erosion experiments suggests the possibility that these

631 sediments are at least periodically eroded, decreasing the impact of biodeposits on sediments

632 under the farm. The high variability in erosion at the higher shear velocity levels (Fig. 6)

633 suggests sediment erosion occurs suddenly and at shear velocities exceeded only at the highest

634 flow rates recorded by the ADV during the $\sim 23 \mathrm{hr}$ deployment. This is likely because a

635 microphytobenthic mat stabilizes surface sediments, resisting erosion until a point of critical

636 failure; this is consistent with the high chl-a values measured in the incubation cores and with the

637 divers' observations of patchiness in the mat cover of the sediment surface (Fig. 2). Though only

638 observed in one of our replicate cores, the partial mat failure at the highest tested shear velocity 
$639\left(2.32 \mathrm{~cm} \mathrm{~s}^{-1}\right)$ falls within the broad range of shear velocities at which biofilms fail. Walker \&

640 Grant (2009) performed erosion experiments on sand and sandy mud sediments with patchy

641 cyanobacterial mats beneath mussel long lines, observing mat failure at around $1.5 \mathrm{~cm} \mathrm{~s}^{-1}$. Grant

$642 \&$ Gust (1987), however, examined erosion of purple sulfur bacteria and cyanobacteria biofilms

643 on sand and found critical friction velocity increased from around $1 \mathrm{~cm} \mathrm{~s}^{-1}$ for clean sands to

644 around $4 \mathrm{~cm} \mathrm{~s}^{-1}$ on sands with biofilms.

645 Massive sediment erosion was not observed in our lab experiments, even as the shear

646 velocities tested exceeded the maximum calculated from the measured in situ bottom flow (Fig.

647 5A). However, the in situ bottom flow was measured only for a short period during neap tide,

648 and higher flow velocities during spring tides would substantially increase shear on the bottom

649 because bed shear stress is proportional to the square of current velocity. Using data from the

650 LOBO station, we predicted that bottom velocity during the time of greatest flow in the spring-

651 neap cycle that summer reached $40 \mathrm{~cm} \mathrm{~s}^{-1}$, driving bottom shear velocities close to $3 \mathrm{~cm} \mathrm{~s}^{-1}$.

652 This would be well above the shear velocity that resulted in partial mat failure in our erosion

653 experiments. Erosion of surface sediment under the farm during maximum velocities of spring

654 tides probably flushed the deposited sediment away from the farm. The periodic peaks in surface

655 turbidity at spring tides observed in the long-term record are consistent with episodic erosion and

656 flushing of biodeposits. Relatively high eroded mass at 2 of the 3 replicates from beneath the

657 farm suggests some flushing of recent biodeposits may have also occurred during the neap tide in

658 which our observations were made (Fig. 6). The poor sorting of sediments at both sites at surface

659 and depth, however, suggests that bulk subsurface sediments do not undergo frequent erosion

660 and deposition events (Fig. 8A, Table S1). Frequent erosion and redeposition tends to result in

661 graded deposition due to gravity sorting and therefore well-sorted sediment profiles (e.g., 
662 Morton, 1988). It therefore seems likely that erosion is limited to surface, recently deposited

663 sediments and that these sediments are not redeposited in bulk around the farm.

664

665 CONCLUSIONS

666 We estimate that, during neap tide in this system, the average oyster biodeposit released

667 in the deep section of the farm may be tidally transported up to $118 \mathrm{~m}$ before reaching the

668 benthos. Our away site at $90 \mathrm{~m}$ distance would therefore be expected to fall within the farm

669 footprint. Though our site comparison indicated no difference between the away site and the

670 farm site, the lack of sediment organic enrichment suggests that this may be because

671 biodeposition is generally low and is not resulting in harmful impacts at either site.

672 Furthermore, the combined observations from the erosion experiments and consideration

673 of maximum flow rates during other times in the tidal cycle suggest a tidally-driven erosion-

674 deposition scenario; biodeposits accumulate and microalgal mats form on the sediment surface

675 within the footprint during the low-energy tidal period. Then, as flow rates increase during spring

676 tide, the bed experiences sudden failure as increased flow velocities produce bottom flow greater

677 than the critical shear velocity and surface sediment detaches from the benthos in fragments,

678 resulting in patchiness that contributes to highly variable fluxes. Periodic, sudden mass failure of

679 sediment integrity would also disturb sessile macrofauna, which have more difficulty surviving

680 physical disturbance than mobile taxa (Brenchley, 1981). Loss of microalgal biomass due to

681 erosion may reduce the favorability of the sediment to settling macrofauna which generally

682 prefer settling on algal biofilm-covered sediment to bare sediment (Pillay et al., 2007; Van Colen

683 et al., 2009). The switching between deposition and erosion would cycle based on tidal flow,

684 intermittently "clearing" patches of sediment under the farm and preventing excessive buildup of 
685 biodeposits. Particularly given the large range of flow velocities this area can experience, future 686 investigations into this possible scenario should conduct sampling at several times throughout the 687 spring-neap tidal cycle to get a full picture of how physical forcing affects aquaculture waste 688 deposition and erosion. Additionally, more spatial sampling should be conducted to corroborate a 689 calculated footprint with an actual footprint, and more comprehensively map the farm's area of 690 influence and resolve uncertainty as to the impact of biodeposition.

691

\section{ACKNOWLEDGEMENTS}

693

Our thanks to Bill Mook, Jeff Auger, and Meredith White at Mook Sea Farm for their

694 help and the use of the Perkins Point farm as our study site, and the University of Maine's

695 Darling Marine Center for accommodations and use of their facilities. Special thanks to Kathleen 696 Thornton for DIC measurements, Larry Mayer and Lee Smee for helpful discussions, and our 697 reviewers for their thoughtful suggestions.

698

699 LITERATURE CITED

700 Aller JY, Stupakoff I (1996) The distribution and seasonal characteristics of benthic 701

702 communities on the Amazon shelf as indicators of physical processes. Cont Shelf Res $16: 717-751$

Aller RC (2004) Conceptual models of early diagenetic processes: the muddy seafloor as an unsteady, batch reactor. J Mar Res 62:815-835

An S, Joye SB (2001) Enhancement of coupled nitrification-denitrification by benthic photosynthesis in shallow estuarine sediments. Limnol Oceanogr 46:62-74 
707 Bianchi TS, Dawson R, Sawangwong P (1988) The effects of macrobenthic deposit-feeding on 708 the degradation of chloropigments in sandy sediments. J Exp Mar Biol Ecol 122:243-255

709 Brenchley GA (1981) Disturbance and community structure: an experimental study of

710 bioturbation in marine soft-bottom environments. J Mar Res 39:767-790

711 Brooks DA (2009) Circulation and dispersion in a cancellate coast: The rivers, bays and estuaries of central Maine. Estuar Coast Shelf Sci 83:313-325

713 Callier MD, Weise AM, McKindsey CW, Desrosiers G (2006) Sedimentation rates in a suspended mussel farm (Great-Entry Lagoon, Canada): biodeposit production and dispersion. Mar Ecol Prog Ser 322:129-141

716 Callier MD, Richard M, McKindsey CW, Archambault P, Desrosiers G (2009) Responses of benthic macrofauna and biogeochemical fluxes to various levels of mussel biodeposition: An in situ "benthocosm" experiment. Mar Pollut Bull 58:1544-1553

Cerco CF, Seitzinger SP (1997) Measured and modeled effects of benthic algae on eutrophication in Indian River-Rehoboth Bay, Delaware. Estuaries 20:231-248

Comeau LA, Mallet AL, Carver CE, Guyondet T (2014) Impact of high-density suspended oyster culture on benthic sediment characteristics. Aquacult Eng 58:95-102

Crawford CM, Macleod CKA, Mitchell IM (2003) Effects of shellfish farming on the benthic

Decho AW, Lopez GR (1993) Exopolymer microenvironments if microbial flora: multiple and interactive effects on trophic relationships. Limnol Oceanogr 38 (8):1633-1645 Caffray T, Budai S, Bell S (2020) Sublethal effects of oil exposure on infaunal behavior, bioturbation, and sediment oxygen consumption Mar Ecol Prog Ser 635:9-24 
730 Dowd, M (2005) A bio-physical coastal ecosystem model for assessing environmental effects of

731 marine bivalve aquaculture. Ecol Modelling 183:323-346

732 FAO (2018) The State of World Fisheries and Aquaculture 2018 - Meeting the sustainable 733 development goals. Rome. Licence: CC BY-NC-SA 3.0 IGO.

734 Findlay RH, Watling L (1997) Prediction of benthic impact for salmon net-pens based on the 735 balance of benthic oxygen supply and demand. Mar Ecol Prog Ser 155:147-157

736 Folk RL,Ward WC (1957) A study in the significance of grain-size parameters. J Sediment

$737 \quad$ Petrol 27:3-26

738 Forrest BM, Keeley NB, Hopkins GA, Webb SC, Clement DM (2009) Bivalve aquaculture in 739 estuaries: Review and synthesis of oyster cultivation effects. Aquaculture 298:1-15

740 Gardner, W (1980) Sediment trap dynamics and calibration: a laboratory evaluation. J Mar Res $741 \quad 38: 17-39$

742 Garrett C (1972) Tidal resonance in the Bay of Fundy and Gulf of Maine. Nature 238:441-443

743 Gentry RR, Froehlich HE, Grimm D, Kareiva P, Parke M, Rust M, Gaines SD, Halpern BS (2017) Mapping the global potential for marine aquaculture. Nat Ecol Ev 1:1317-1324

745 Giles H, Pilditch CA, Bell DG (2006) Sedimentation from mussel (Perna canaliculus) culture in 746 the Firth of Thames, New Zealand: Impacts on sediment oxygen and nutrient fluxes.

$747 \quad$ Aquaculture 261:125-140

748 Grant J, Gust G (1987) Prediction of coastal sediment stability from photopigment content of mats of purple sulphur bacteria. Nature 330:244-246

750 Grant J, Hatcher A, Scott DB, Pocklington P, Schafer CT, Winters GV (1995) A multidisciplinary approach to evaluating impacts of shellfish aquaculture on benthic communities. Estuaries 18:124-44 
753 Green Eyes LLC. (2015) U-GEMS Manual Version 3.0. 0-44

754 Gust G, Muller V (1997) Interfacial hydrodynamics and entrainment functions of currently used

755

756

757

758

759

760

761

762

763

764

765

766

767

768

769

770

771

772

773

774 erosion devices. In: Cohesive Sediments:4th Nearshore and Estuarine Cohesive Sediment Transport Conference, INTERCOH '94. Wiley, New York, USA, p 149-174

Hansen K, Kristensen E (1997) Impact of Macrofaunal Recolonization on Benthic Metabolism and Nutrient Fluxes in a Shallow Marine Sediment Previously Overgrown with Macroalgal Mats. Estuarine, Coast Shelf Sci 45:613-628

Haven D, Morales-Alamo R (1966) Aspects of Biodeposition by Oysters and Other Invertebrate Filter Feeders. Limnol Oceanogr 11:487-498

Haven D, Morales-Alamo R (1972) Biodeposition as a Factor in Sedimentation of Fine Suspended Solids In Estuaries. In: Nelson B (ed) Environmental Framework of Coastal Plain Estuaries. The Geological Society of America, Columbia, South Carolina, USA, p 121-130

Higgins CB, Tobias C, Piehler MF, Smyth AR, Dame RF, Stephenson K, Brown BL (2013) Effect of aquacultured oyster biodeposition on sediment $\mathrm{N}_{2}$ production in Chesapeake Bay. Mar Ecol Prog Ser 473:7-27

Kaiser MJ, Laing I, Utting SD, Burnell GM (1998) Environmental impacts of bivalve mariculture. J Shellfish Res 17:59-66

Kim SC, Friedrichs CT, Maa JY, Wright LD (2000) Estimating bottom stress in tidal boundary layer from acoustic Doppler velocimeter data. J Hydraul Eng 126:399-406

Kobayashi M, Msangi S, Batka M, Vannuccini S, Dey MM, Anderson JL (2015) Fish to 2030: the role and opportunity for aquaculture. Aquacult Econ Manage 19:282-300 
775 Komar, P. D. 1980. Settling velocities of circular cylinders at low Reynolds numbers. Journal of $776 \quad$ Geology 88:327-336.

777 Lehrter JC, Beddick DL, Devereux R, Yates DF, Murrell MC (2012) Sediment-water fluxes of 778 dissolved inorganic carbon, $\mathrm{O}_{2}$, nutrients, and $\mathrm{N}_{2}$ from the hypoxic region of the 779 Louisiana continental shelf. Biogeochemistry, 109(1-3), 233-252.

780 Mallet AL, Carver CE, Landry T (2006) Impact of suspended and off-bottom Eastern oyster 781 culture on the benthic environment in eastern Canada. Aquaculture 255:362-73

782 McAlice BJ (1977) A preliminary oceanographic survey of the Damariscotta River estuary, 783 Lincoln County, Maine. Maine Sea Grant Technical Report.

784 Meijering E, Dzyubachyk O, Smal I (2012) Methods for Cell and Particle Tracking. Methods $785 \quad$ Enzymol 504:183-200.

786 Mirto S, La Rosa T, Danovaro R, Mazzola A (2000) Microbial and Meiofaunal Response to 787 Intensive Mussel-Farm Biodeposition in Coastal Sediments of the Western 788 Mediterranean. Marine Pollution Bulletin 40(3): 244-252.

Mitchell IM (2006) In situ biodeposition rates of Pacific oysters (Crassostrea gigas) on a marine farm in Southern Tasmania (Australia). Aquaculture 257:194-203

791 Montserrat F, Van Colen C, Degraer S, Ysebaert T, Herman, PMJ (2008) Benthic communitymediated sediment dynamics. Mar Ecol Prog Ser 372:43-59

793

Morton RA (1988) Nearshore responses to great storms. Spec Pap Geol Soc Am 229:7-22

794 Navas JM, Telfer TC, Ross LG (2011) Application of 3D hydrodynamic and particle tracking 795 models for better environmental management of finfish culture. Cont Shelf Res 31:675-

796 684 
797 Newell RI (2004) Ecosystem influences of natural and cultivated populations of suspension-

798 feeding bivalve molluscs: A review. J Shellfish Res 23:51-62

799 Newell RI, Cornwell JC, Owens MS (2002) Influence of simulated bivalve biodeposition and

800 microphytobenthos on sediment nitrogen dynamics: a laboratory study. Limnol and

$801 \quad$ Oceanogr 47(5):1367-79

802 Paltzat DL, Pearce CM, Barnes PA, McKinley RS (2008) Growth and production of California 803 sea cucumbers (Parastichopus californicus Stimpson) co-cultured with suspended Pacific $804 \quad$ oysters (Crassostrea gigas Thunberg). Aquaculture 275:124-137

805 Pearson TH, Rosenberg R (1978) Macrobenthic succession in relation to organic enrichment and 806 pollution of the marine environment. Oceanogr Mar Biol Ann Rev 16:229-311

807 Pieterse A, Puleo JA, McKenna TE, Aiken RA (2015) Near-bed shear stress, turbulence 808 production and dissipation in a shallow and narrow tidal channel. Earth Surf Process $809 \quad$ Landf 40:2059-2070

810 Pillay D, Branch GM, Forbes AT (2007) Effects of Callianassa kraussi on microbial biofilms 811 and recruitment of macrofauna: a novel hypothesis for adult-juvenile interactions. Mar $812 \quad$ Ecol Prog Ser 347:1-14

813 R Core Team. (2016) R: a language and environment for statistical computing.

814 [Online]. R Foundation for Statistical Computing, Vienna. Available:

815 https://www.R-project.org/ [2019, January 31].

816 Reay WG, Gallagher DL, Simmons GMJ (1995) Sediment-water column oxygen and nutrient 817 fluxes in nearshore environments of the lower Delmarva Peninsula, USA. Mar Ecol Prog $818 \quad$ Ser 118:215-227

819 Richard M, Archambault P, Thouzeau G, Desrosiers G (2007) Summer influence of 1 
and 2 yr old mussel cultures on benthic fluxes in Grande-Entrée lagoon, Îles-de-la-

821 Madeleine (Québec, Canada). Mar Ecol Prog Ser 338:131-143

822 Rysgaard S, Thamdrup B, Risgaard-Petersen N, Fossing H, Berg P, Christensen PB, Dalsgaard T

823 (1998) Seasonal carbon and nutrient mineralization in a high-Arctic coastal marine 824 sediment, Young Sound, Northeast Greenland. Mar Ecol Prog Ser 175:261-76

825 Schneider CA, Rasband WS, Eliceiri KW (2012) NIH Image to ImageJ: 25 years of image 826 analysis. Nat methods 9:671-675

Sherwood CR, Lacy JR, Voulgaris G (2006) Shear velocity estimates on the inner shelf off Grays Harbor, Washington, USA. Cont Shelf Res 26:1995-2018

Silva E, Garbossa LHP, Nuñer APO, Lapa KR (2019) Hydrodynamic modelling of the dispersion and deposition of biodeposits from marine bivalve mollusc farming under neap and spring tides in Santa Catarina Island Bays. Aquaculture 501:507-514

832 Sundbäck K, Graneli W (1988) Influence of microphytobenthos on the nutrient flux between sediment and water: a laboratory study. Mar Ecol Prog Ser 43:63-69

834 Tengberg, A, Stahl H, Gust G, Muller V, Arning U, Andersson H, Hall POJ (2004) Intercalibration of benthic flux chambers I. Accuracy of flux measurements and influence of chamber hydrodynamics. Prog Oceanogr 60:1-28

837 Testa J, Brady C, Cornwell J, Owens M, Sanford L, Newell C, Suttles S, Newell R (2015) 838 Modeling the impact of floating oyster (Crassostrea virginica) aquaculture on sedimentwater nutrient and oxygen fluxes. Aquacult Environ Interact 7:205-222

840

Thomsen L, Gust G (2000) Sediment erosion thresholds and characteristics of resuspended 841 aggregates on the western European continental margin. Deep Sea Res I 47:1881-1897 
842 U.S. EPA (2009) Standard Operating Procedure for the Analysis of PC/PN Using the CE $843 \quad$ Elantech Flash EA.

844 Van Colen C, Lenoir J, De Backer A, Vanelslander B, Vincx M, Degraer S, Ysebaert T (2009)

845 Settlement of Macoma balthica larvae in response to benthic diatom films. Mar Biol $846 \quad 156: 2161-2171$

847 Walker TR, Grant J (2009) Quantifying erosion rates and stability of bottom sediments at mussel 848 aquaculture sites in Prince Edward Island, Canada. J Mar Syst 75:46-55

849 Watling, L, Findlay RH, Mayer LM, Schick DF (2001) Impact of a scallop drag on the sediment 850 chemistry, microbiota, and faunal assemblages of a shallow subtidal marine benthic $851 \quad$ community. J Sea Res 46:309-324

852 Welschmeyer NA (1994) Fluorometric analysis of chlorophyll a in the presence of chlorophyll b 853 and pheopigments. Limnol Oceanogr 39:1985-1992

854 Widdows J, Blauw A, Heip CHR, Herman PMJ, Lucas CH, Middelburg JJ, Schmidt S, Brinsley 855 MD, Twisk F, Verbeek H (2004) Role of physical and biological processes in sediment 856 dynamics of a tidal flat in Westerschelde Estuary, SW Netherlands. Mar Ecol Prog Ser $857 \quad 274: 41-56$ 


\section{Figure 1}

Map of study area.

The study took place at the Perkins Point location of Mook Sea Farm (marked "Lease" in panel C) in the Damariscotta River (white in panel B) in Maine, USA (A). The farm sits on a sloping shoal, while the surface LOBO buoy is located in the channel.

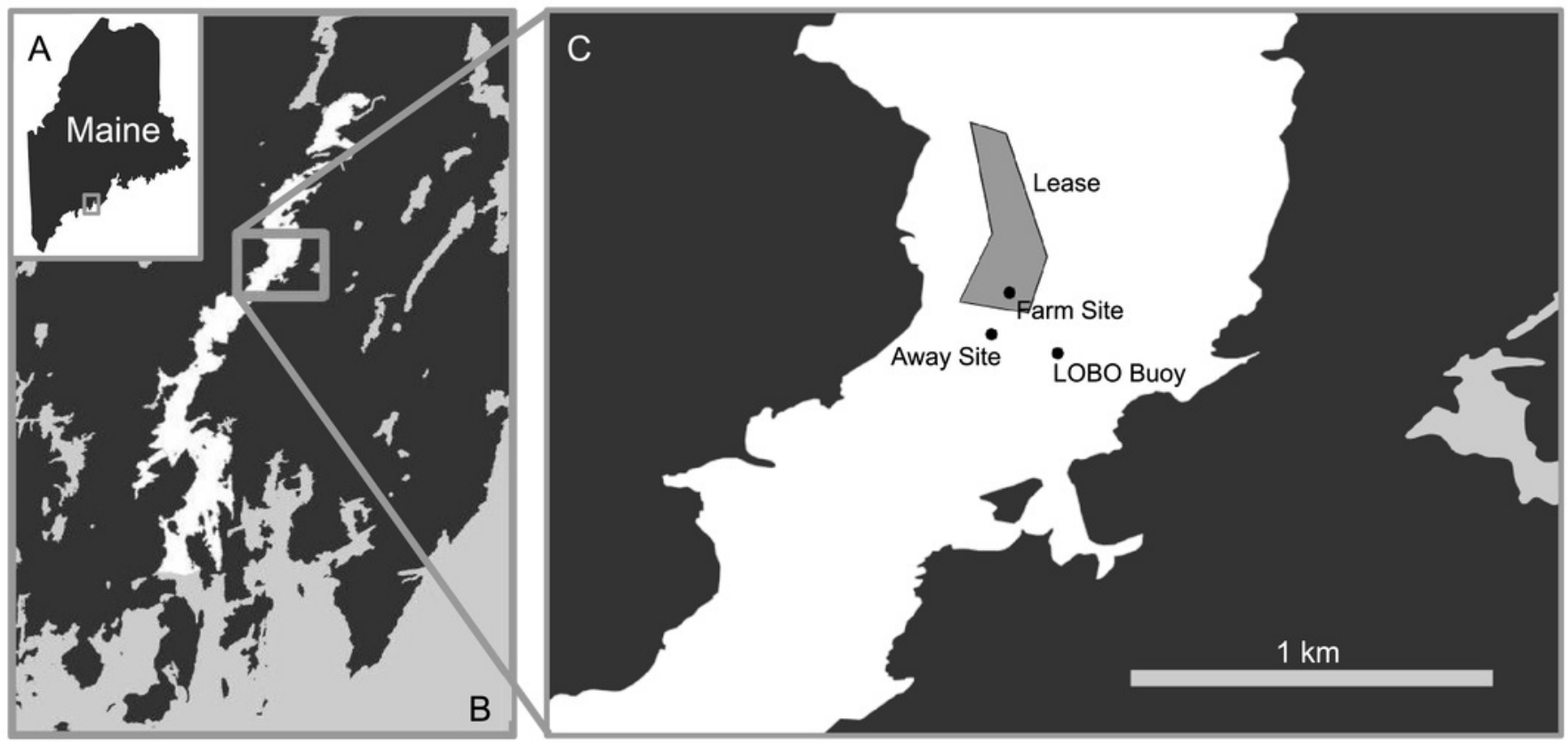




\section{Figure 2}

Images of benthos from diver core collection.

(A) Acrylic core in sediment with sparse microbial mat. (B) Patchy microbial mat on sediment surface. Photo credit: Christopher Rigaud, University of Maine, Scientific Diving Program.
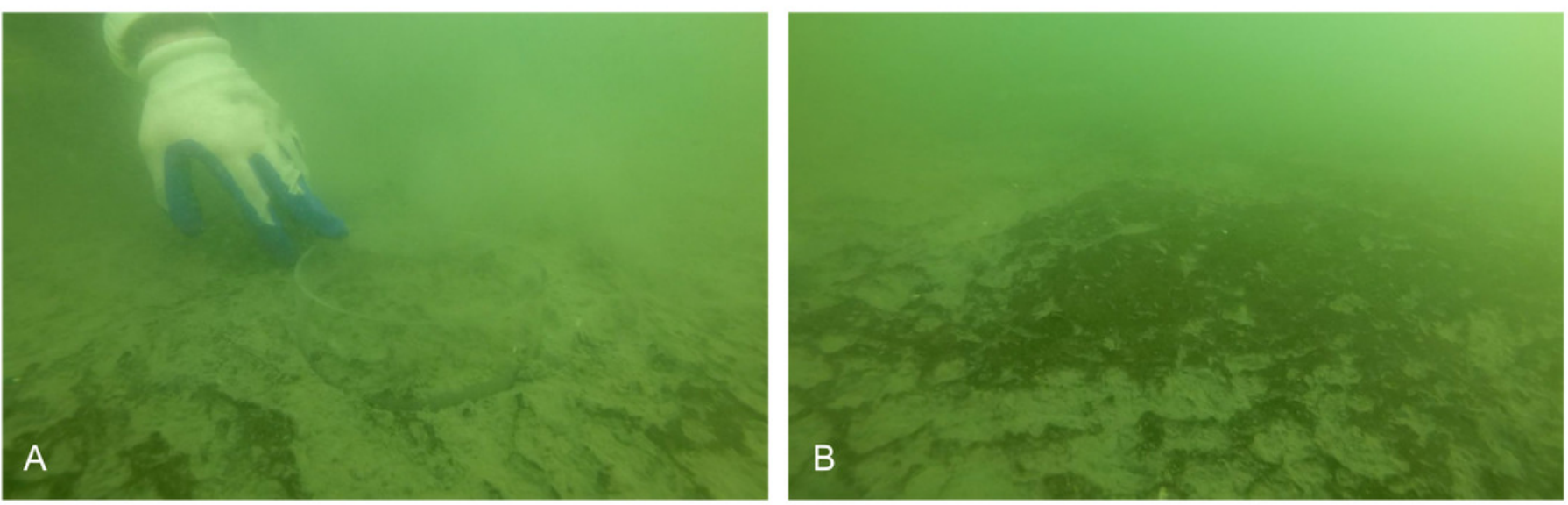
Figure 3

Transport of particles throughout the tidal cycle.

(A) Velocity measured $37 \mathrm{~cm}$ above the bed (black line, $\pm 20 \mathrm{~cm} \mathrm{~s}^{-1}$ ) and water level (gray line, $2.86 \mathrm{~m}$ range) at the farm site, and calculated distances that biodeposit particles travel in the (B) $2 \mathrm{~m}$ depth section and (C) $4 \mathrm{~m}$ depth section of the farm over a $\sim 23 \mathrm{hr}$ period. In panels $B$ and $C$, the thick, darker line is the mean and the thin, lighter lines are the $5^{\text {th }}$ and $95^{\text {th }}$ percentile of particle sizes. Positive values indicate flow and transport in a landward direction, while negative indicates a seaward direction.
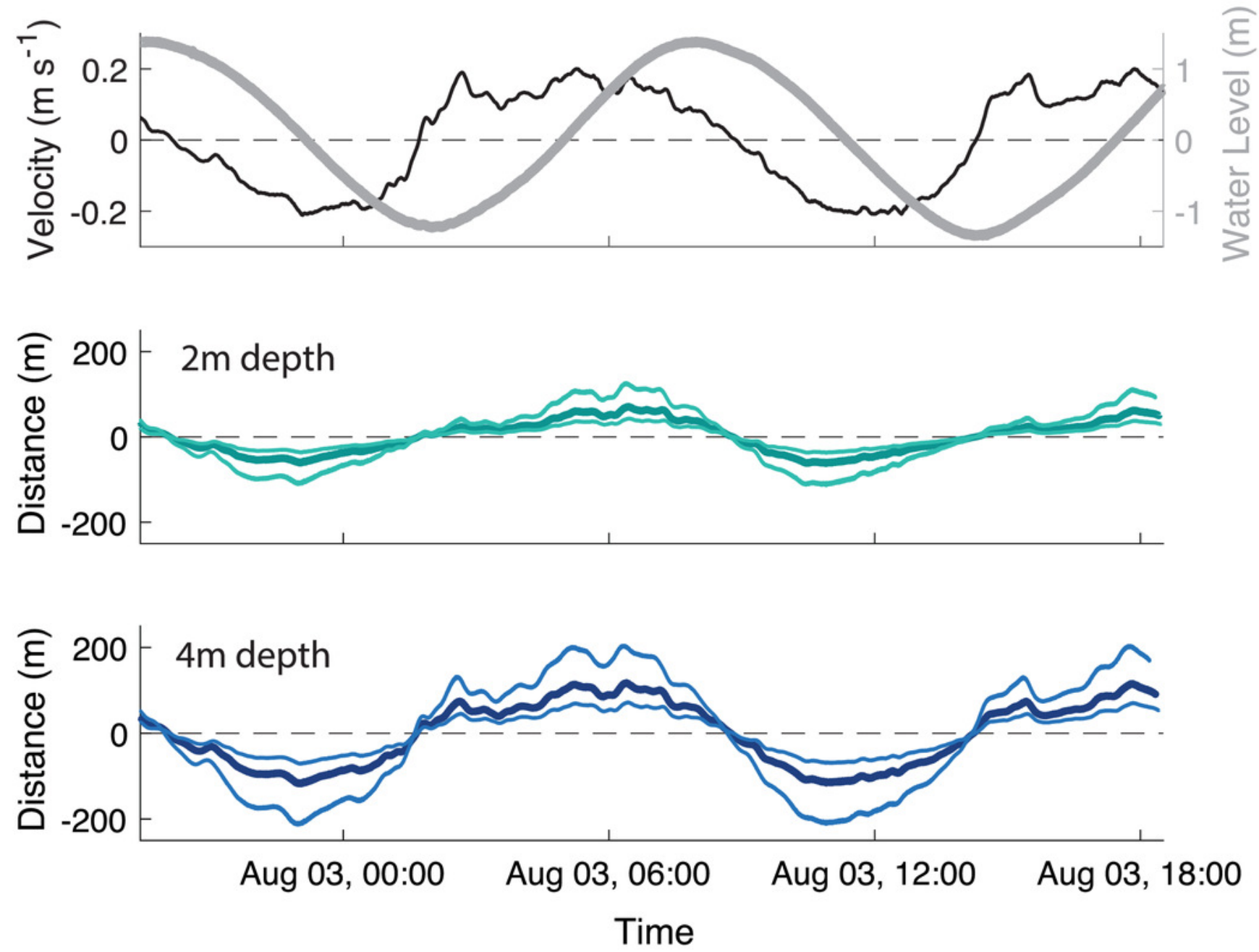
Figure 4

Particle settling velocity plotted as a function of surface area.

Black square represents means of surface area and settling velocity with associated $95 \%$ confidence intervals.

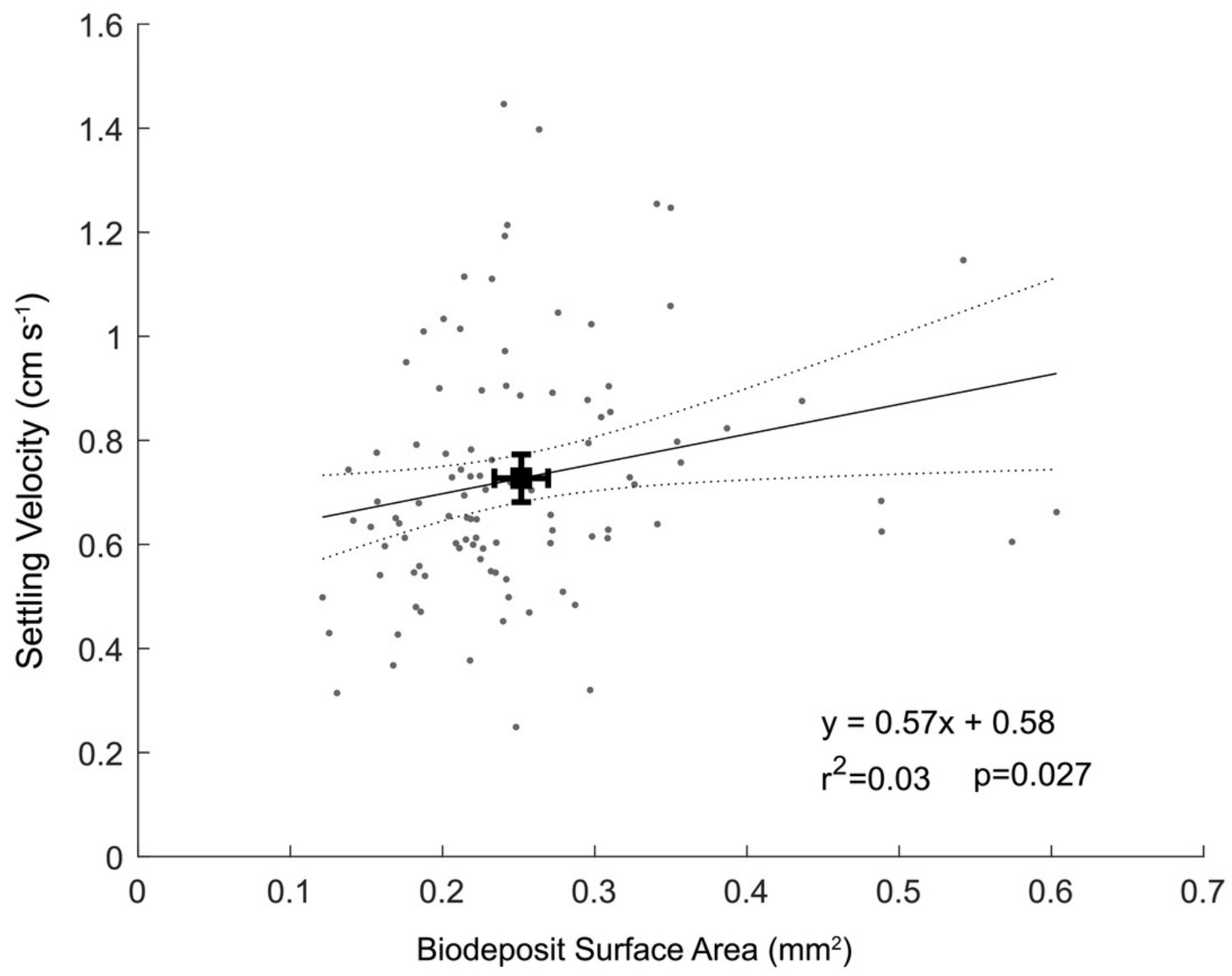




\section{Figure 5}

Shear velocity and effects of shear on bottom.

(A) Time series of the bottom shear velocity $\left(u^{*}\right)$ at the Farm site calculated with three different methods; the logarithmic profile (LP), covariance (COV) and turbulent kinetic energy methods. The laboratory Gust chamber tested shear velocity levels marked with dashed lines. The horizontal line at $\mathrm{u}^{*}=2.01 \mathrm{~cm} \mathrm{~s}^{-1}$ marks the shear velocity level during which aggregates began collecting at the center of a core from the Farm site, shown in B (arrow). The line at $\mathrm{u}^{*}=2.32 \mathrm{~cm} \mathrm{~s}^{-1}$ marks the shear velocity during which partial mat failure was observed on the sediment surface in a core from the Away site, shown in C (arrow). Red marks are on the outside of the core. Photo credit: William C. Clemo. 

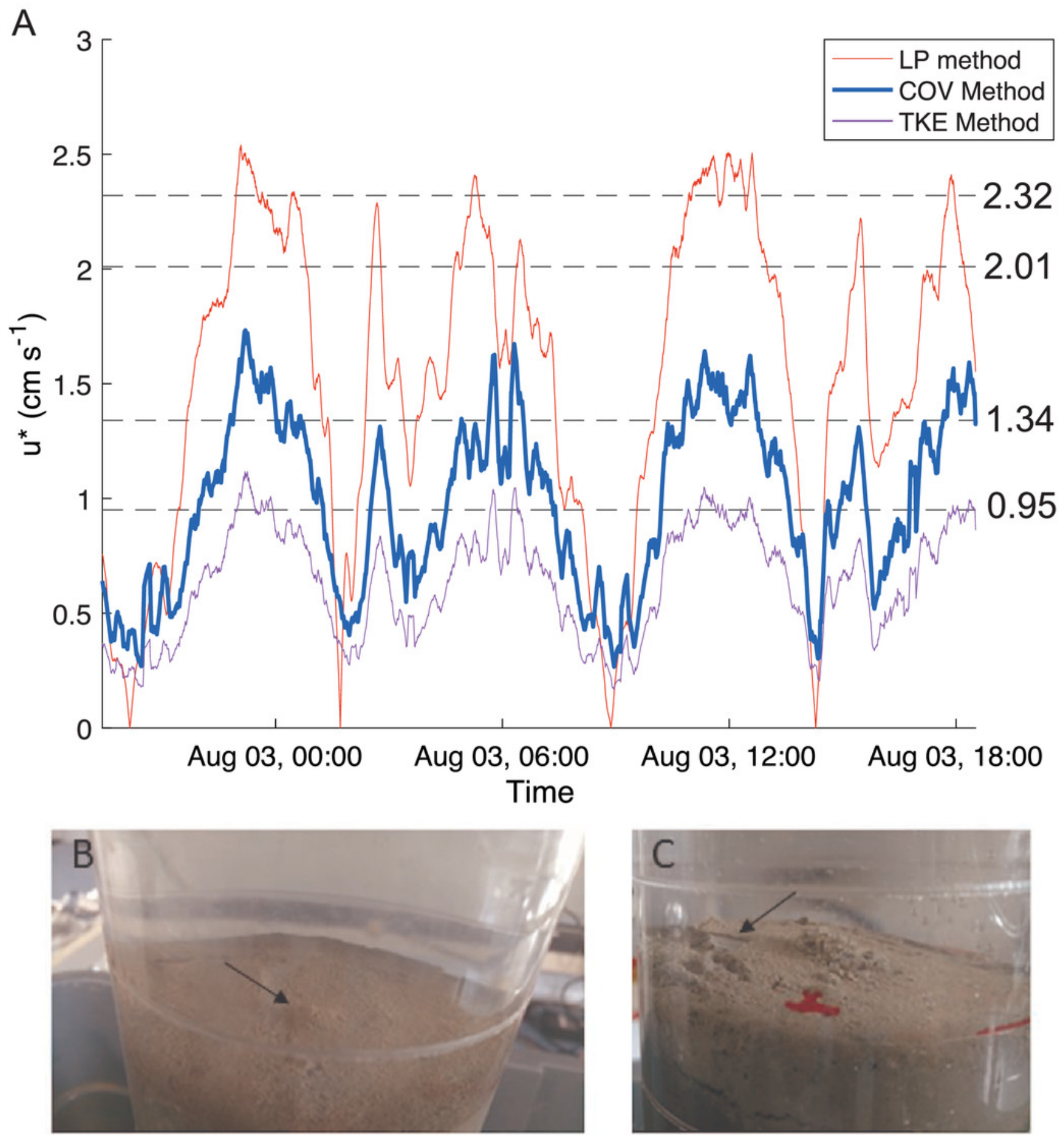
Figure 6

Cumulative eroded mass.

Eroded mass for Farm (brown triangles; $n=3$ ) and Away (blue circles; $n=2$ ) sites at applied $\mathrm{u}^{*}$ (shear velocity) and equivalent $\tau$ (shear stress). Smaller, unfilled symbols are replicates and larger, filled symbols are averages, and bars are \pm one standard deviation.

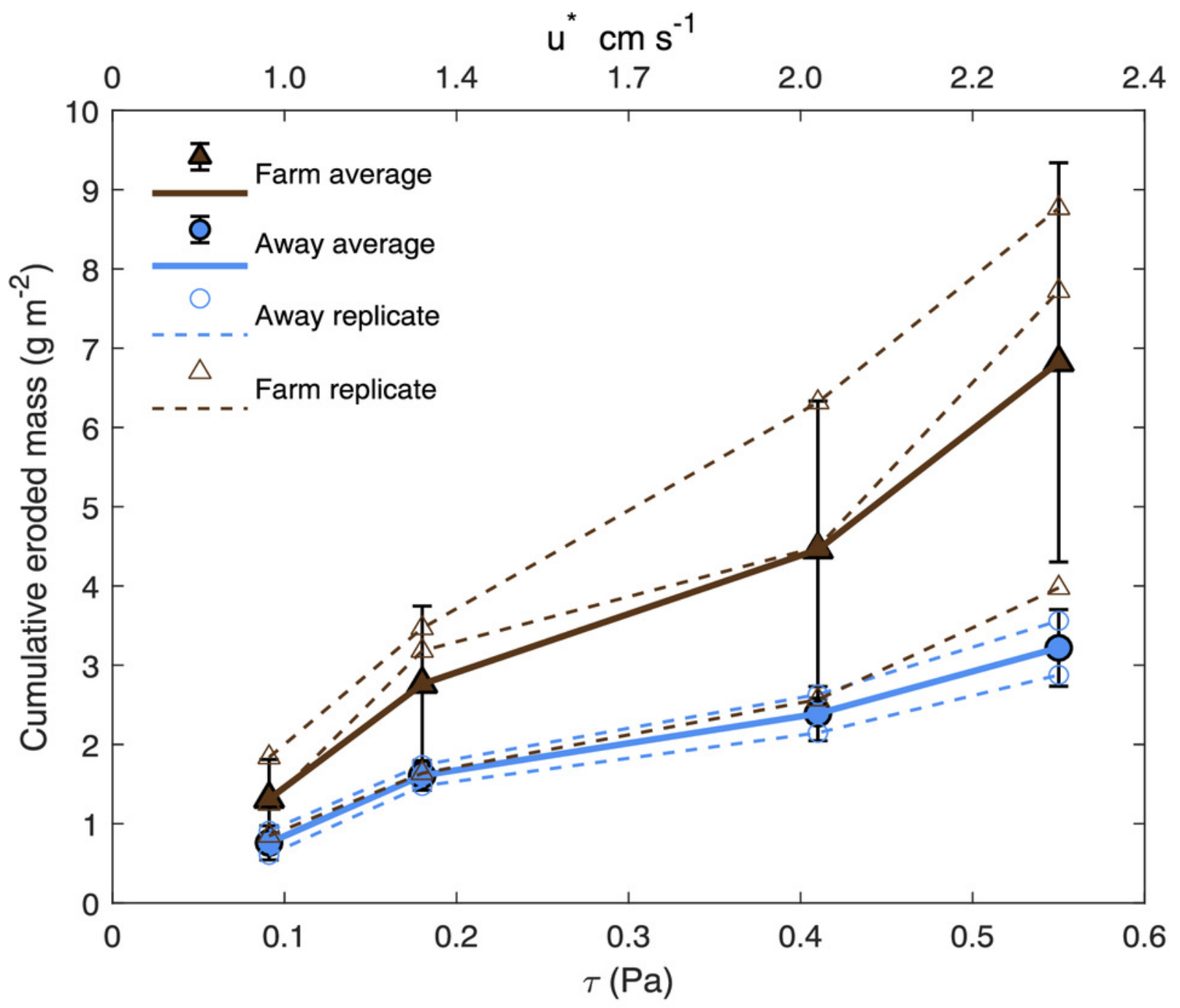


Figure 7

Surface velocity (A) and turbidity (B) during summer 2018.

The 40-hour velocity standard deviation (darker blue line) closely corresponds to the 40-hour low pass filtered turbidity data (darker brown line). Some peaks in turbidity are associated with large precipitation events (triangles). The field survey time is shown with a dashed line. Positive velocity vales show landward flow and negative values show seaward flow.

A

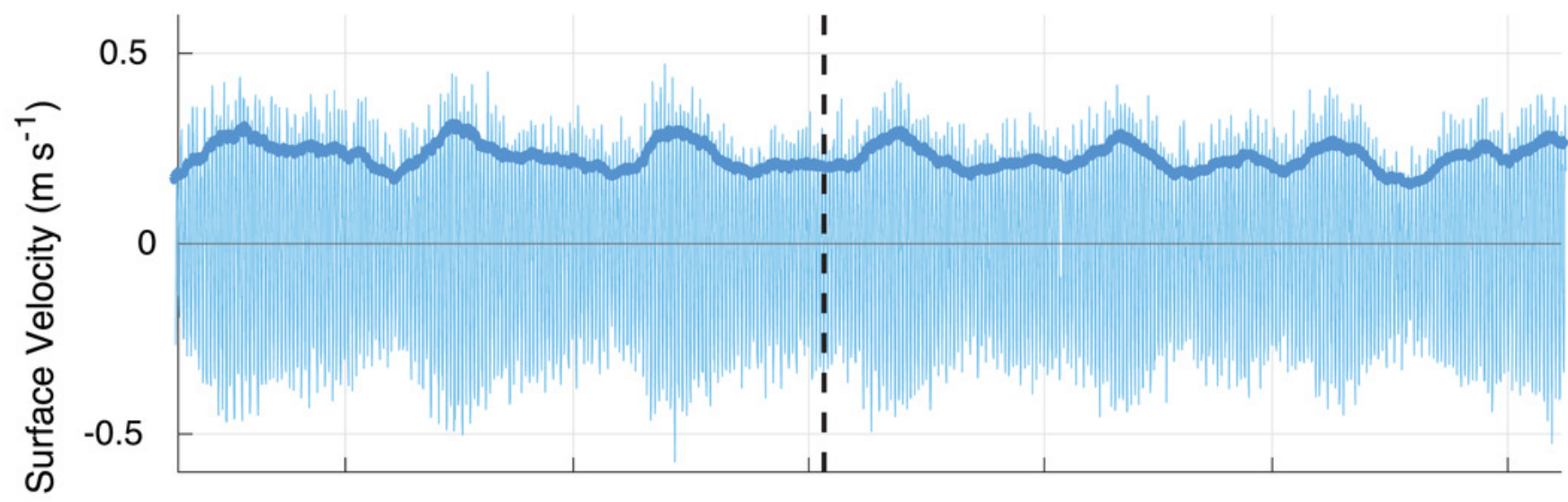

B

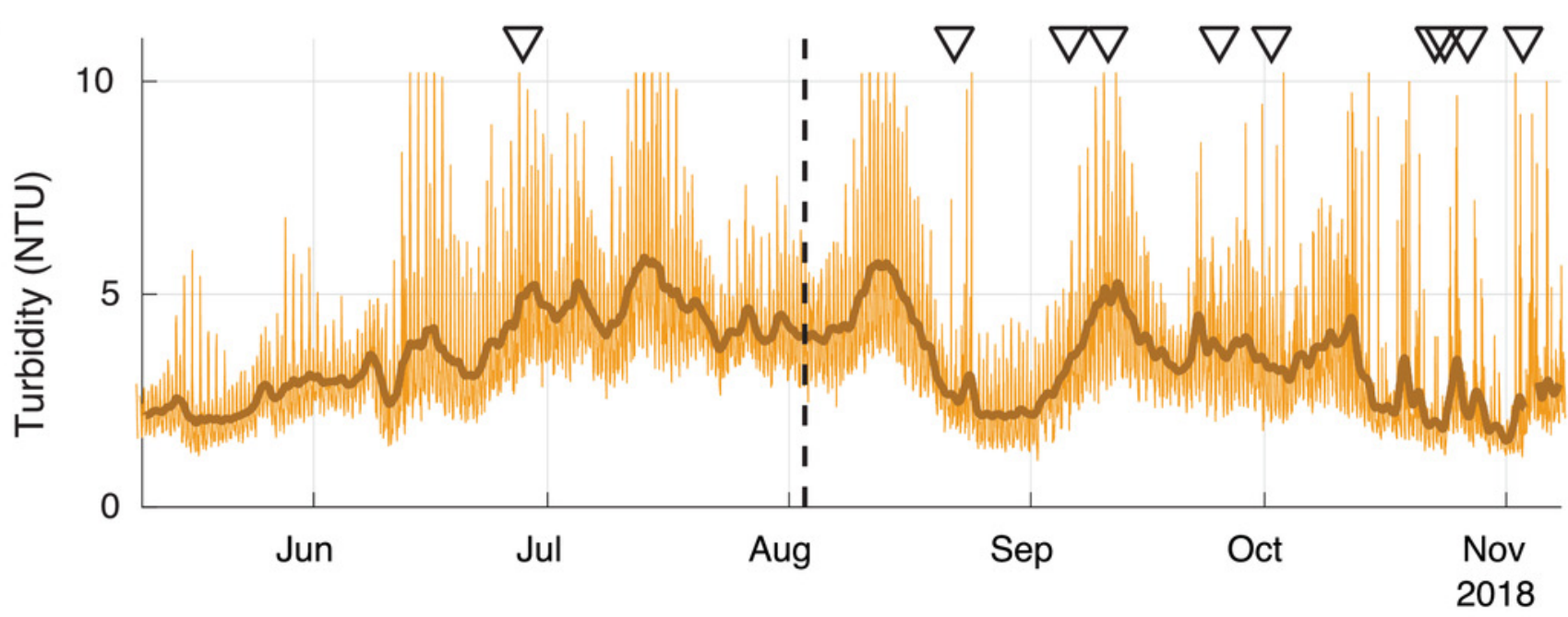


Figure 8

\section{Sediment characteristics.}

(A) grain size distribution in percent for surface $(0-3 \mathrm{~cm})$ and subsurface $(3-7 \mathrm{~cm})$, (B) water content in percent, and (C) percent organic content at the away site (blue line and circles) and farm site (brown line and triangles).
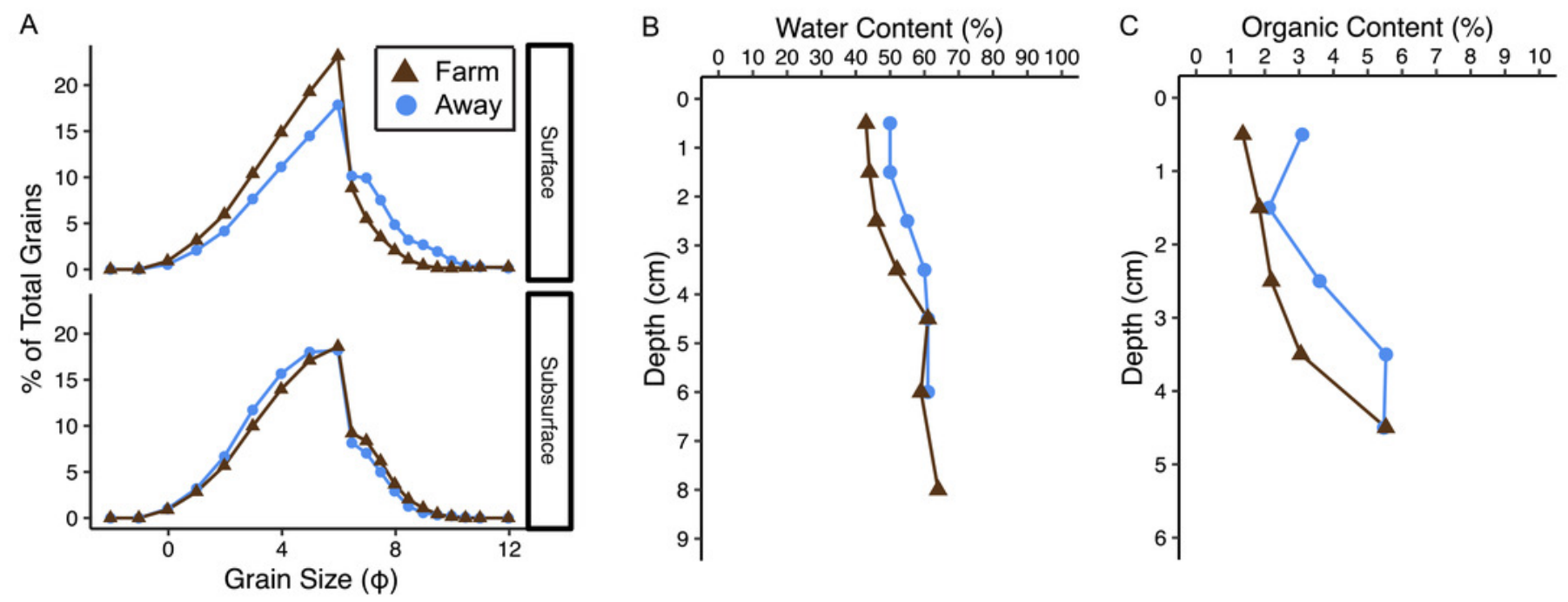


\section{Figure 9}

Sediment biogeochemical fluxes.

(A) Oxygen, (B) DIC, (D) $\mathrm{NH}_{4}{ }^{+}$, and (F) $\mathrm{PO}_{4}{ }^{3-}$ fluxes. Positive value indicates flux out of the sediment. Also shown are relationships between oxygen flux and each nutrient flux (C, E and G). There was no significant relationship between oxygen flux and the DIC or nutrient fluxes. Because oxygen flux could not be measured from the amended cores, no data are shown for that treatment. Error bars are standard deviation. 
A

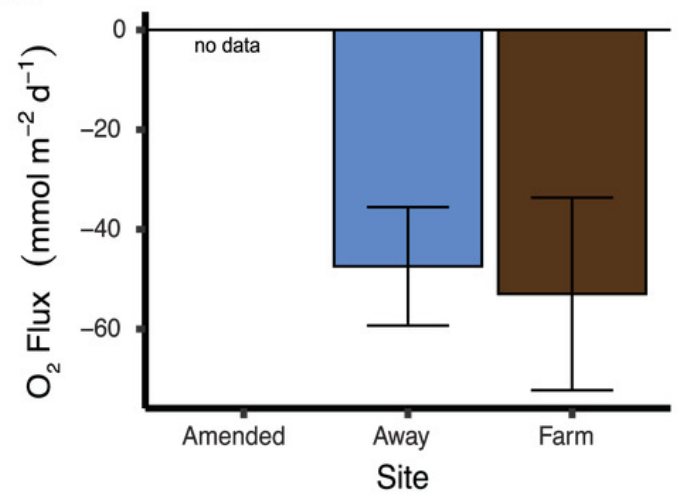

B

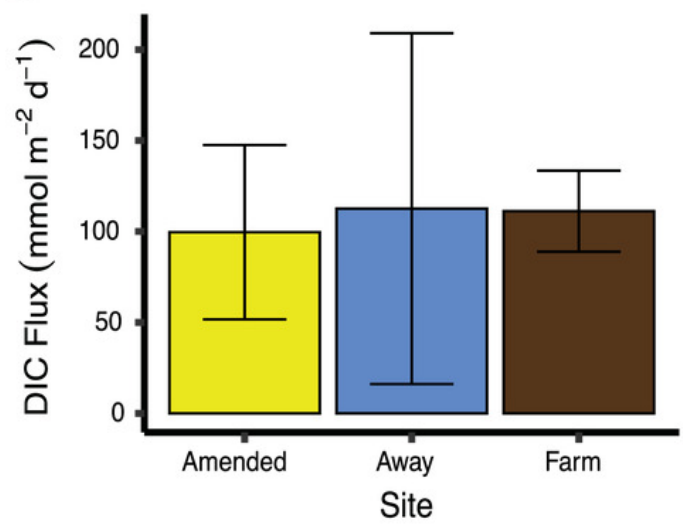

D

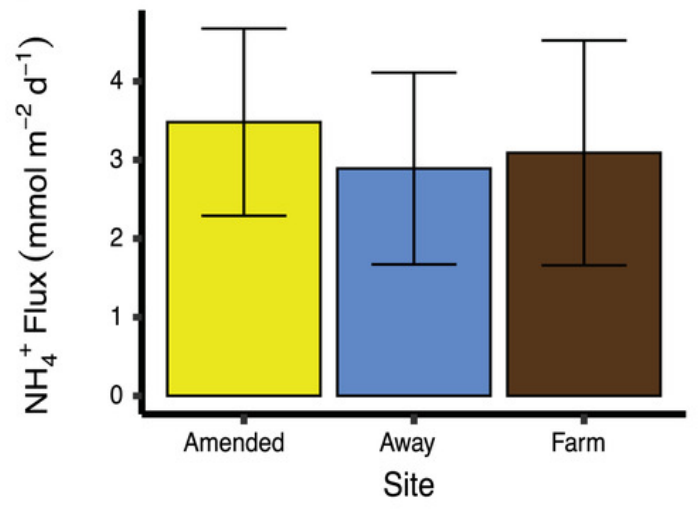

F

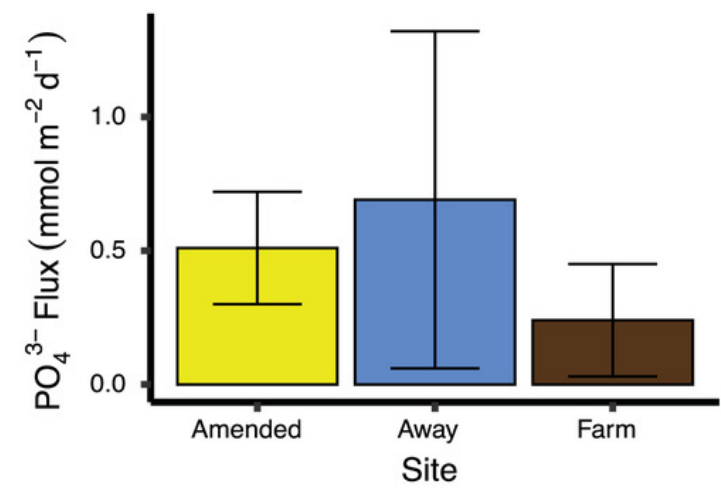

C

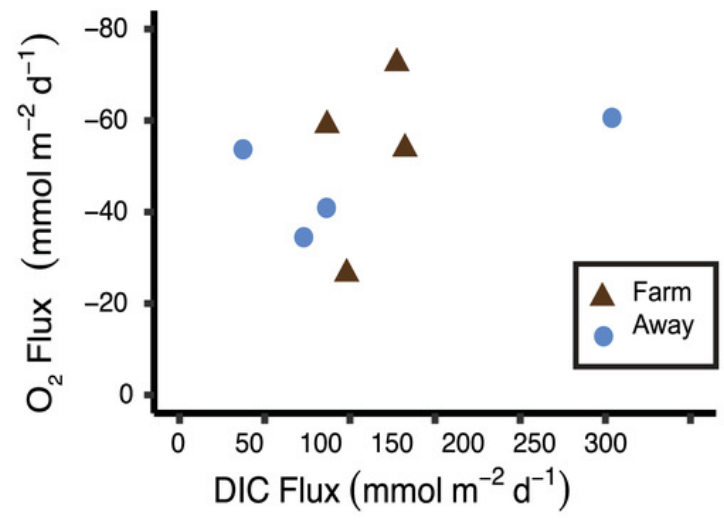

E

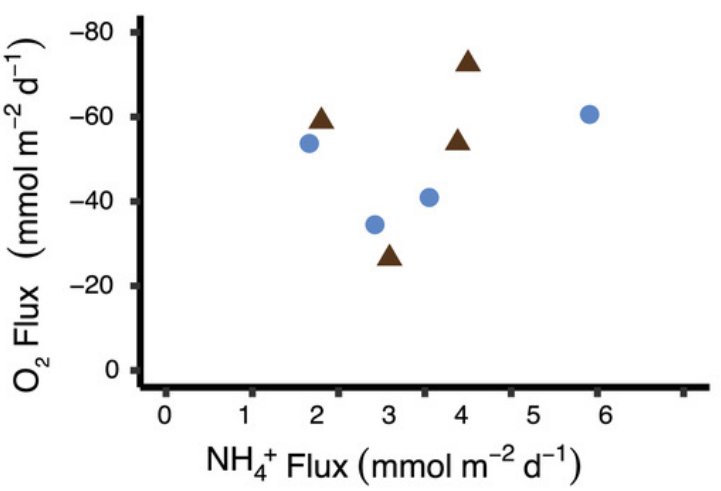

G

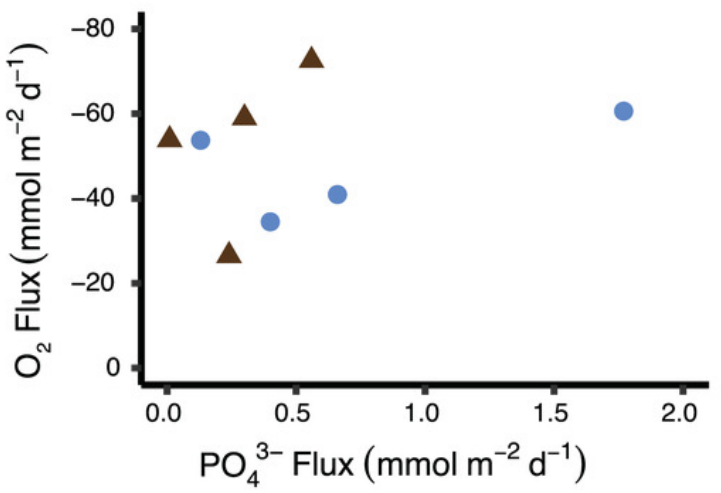




\section{Figure 10}

Macrofaunal community structure.

(A) Average macrofaunal abundance by family for Farm (brown; $n=4$ ) and Away (blue; $n=8$ )

sites. Bars are \pm one standard deviation. (B) Non-metric multidimensional scaling ordination of Farm (brown triangles; $n=4$ ) and Away (blue circles; $n=8$ ) replicate samples based on square-root-transformed macrofaunal abundances and Bray-Curtis similarities (stress $=0.11$ ). Clusters at similarity levels of $20 \%$ (dotted line), $40 \%$ (dashed line) and $60 \%$ (solid line) are indicated. Bold solid line indicates Away replicates with high abundance of small nephtyids. Replicate 3 of the Away sites (Table S3) was excluded from the ordination because no macrofaunal animals were found. 
A

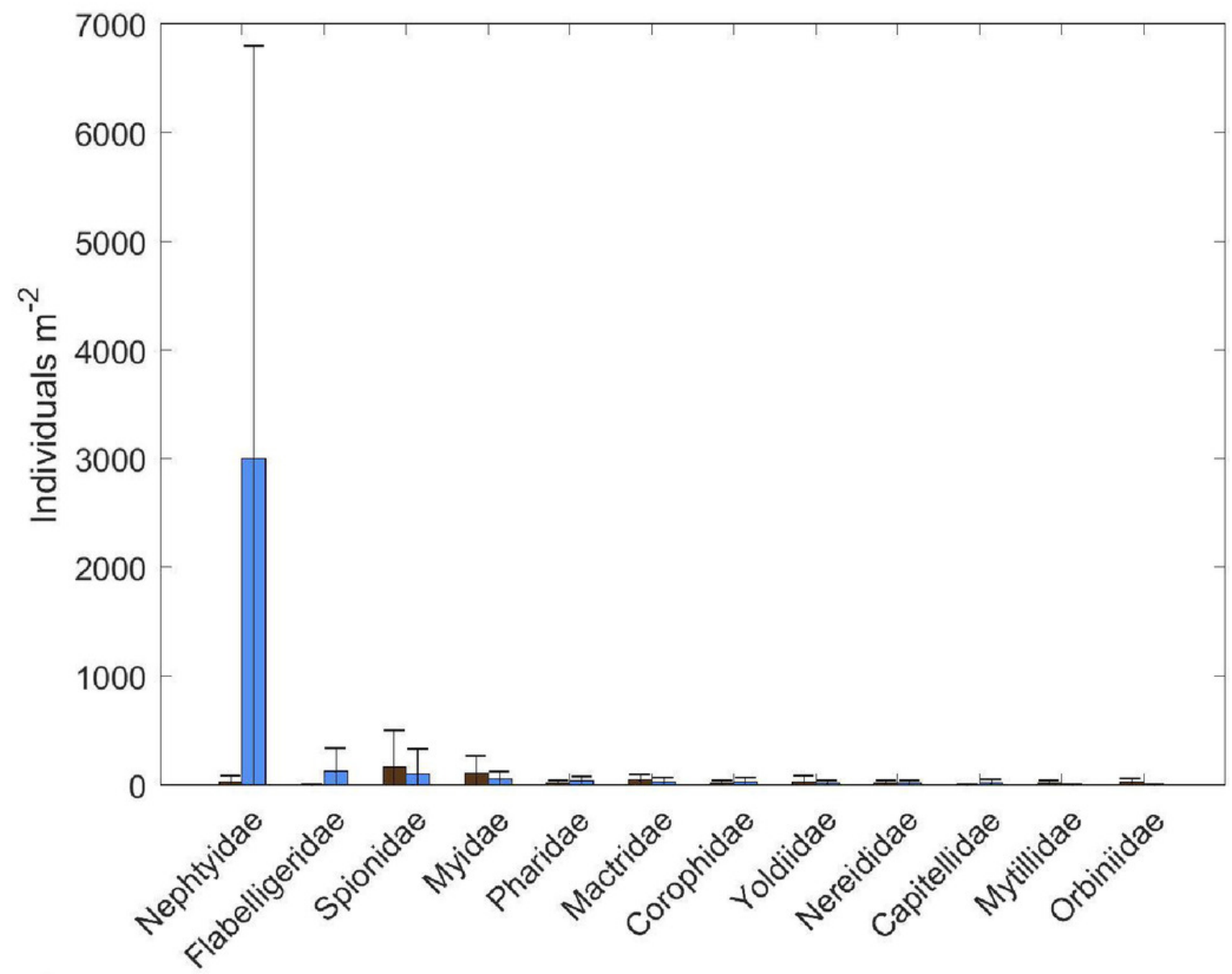

B

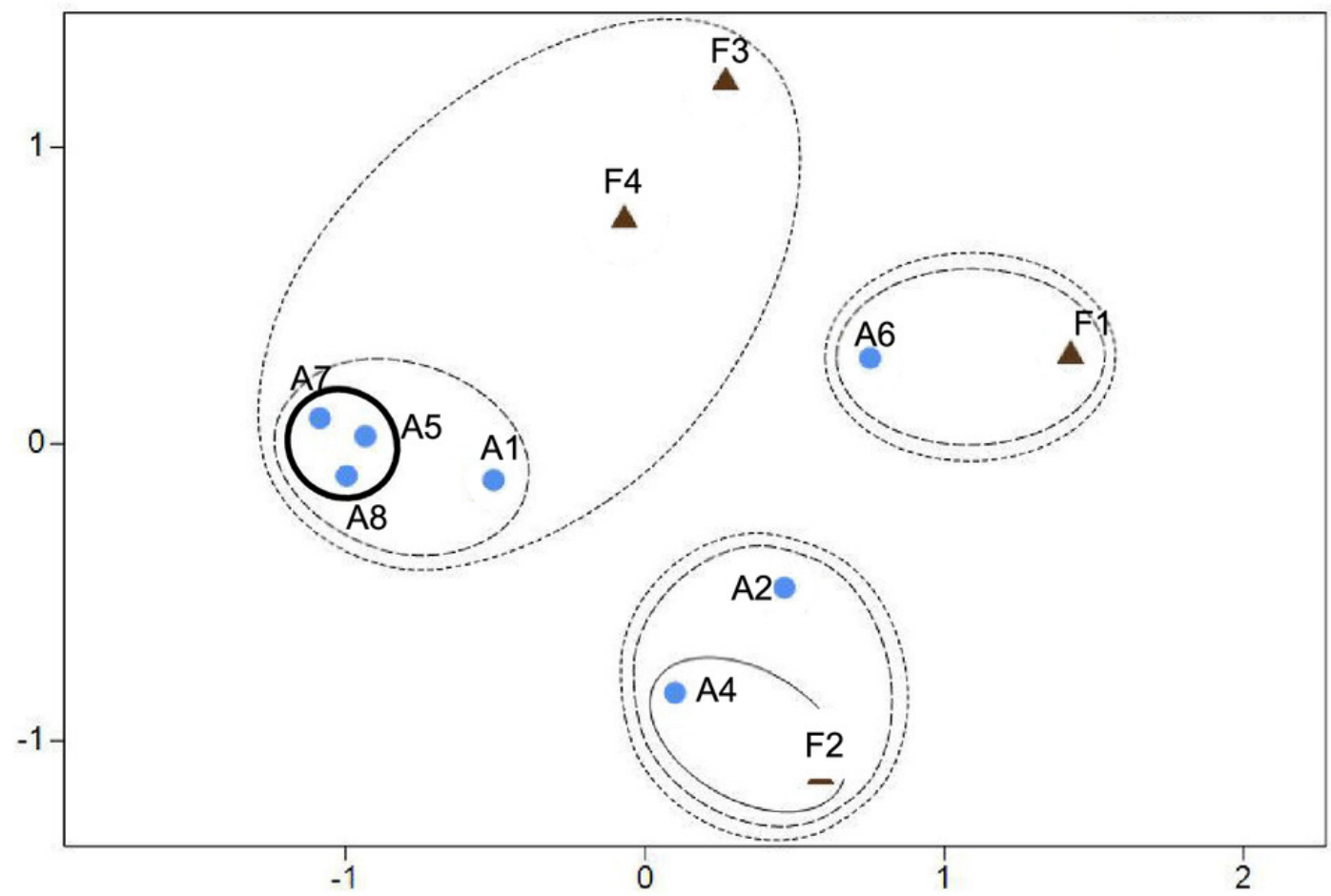

